\title{
SENYAWA INHIBITOR $\alpha$-GLUKOSIDASE DAN ANTIOKSIDAN DARI KUMIS KUCING DENGAN PENDEKATAN METABOLOMIK BERBASIS FTIR
}

\author{
[a-Glucosidase Inhibitor and Antioxidant Compounds from \\ Orthosiphon stamineus Benth Using FTIR Based Metabolomics] \\ Juliani $^{1)}$, Nancy D. Yuliana ${ }^{2,3) \star}$, Slamet Budijanto ${ }^{2)}$, C. Hanny Wijaya ${ }^{2,3)}$, dan Alfi Khatib ${ }^{4)}$ \\ 1) Program Studi llmu Pangan, Sekolah Pasca Sarjana, Institut Pertanian Bogor, Bogor \\ 2) Departemen IImu dan Teknologi Pangan, Fakultas Teknologi Pertanian, Institut Pertanian Bogor, Bogor \\ 3) Pusat Studi Biofarmaka LPPM, Institut Pertanian Bogor, Bogor \\ ${ }^{4)}$ Department of Pharmaceutical Chemistry, Faculty of Pharmacy, International Islamic University Malaysia, Malaysia
}

Diterima 22 April 2016 / Disetujui 24 Juni 2016

\begin{abstract}
Plant is well known as an excellent source for bioactive compounds. Metabolomics was reported as a potential tool to accelerate plant acitive compounds identification. In this research, FTIR-based metabolomics method was used to identify active compounds with $\alpha$-glucosidase inhibitory and antioxidant activity in aerial parts of Orthosiphon stamineus (OS) extract and its fractions. Chemical profile of OS methanolic extracts and hexane, chloroform, butanol, and water fractions were analyzed using infrared spectroscopy. OS extracts and fractions showed inhibitory activity against $\alpha$-glucosidase enzymes with $I C_{50}$ value $154.07 \pm 30.60$ $465.83 \pm 85.34 \mu \mathrm{g} / \mathrm{mL}$ and antioxidant activity with $I C_{50}$ value $7.41 \pm 0.02-19.35 \pm 0.09 \mu \mathrm{g} / \mathrm{mL}$. Butanol fraction was the fraction with the highest $\alpha$-glucosidase inhibitory activity and moderate antioxidant activity with $I C_{50}$ value between $154.07 \pm 30.60 \mu \mathrm{g} / \mathrm{mL}$ and $10.84 \pm 0.54 \mu \mathrm{g} / \mathrm{mL}$, respectively. The correlation between the biological activity and chemical composition data were analyzed using Orthogonal Projections to La tent Structures (OPLS). Based on the VIP (variable influence on projection), the coefficient value of the respective OPLS models, and IR database of compounds previously identified in OS, it was suggested that methoxy flavonoid (sinensitin and 5,6,7,3'-tetramethoxy-4'-hydroxy-8-C-preny-Iflavone), diterpenes (orthosiphols, orthoarisins, neoorthosiphols, staminols, and staminolactones) and triterpenes (ursolic acid, oleanolic acid, betulinic acid, hydroxybetulinic acid, maslinic acid, $\alpha$-amyrin and $\beta$-amyrin) were identified as responsible compounds for the $\alpha$-glucosidase inhibitory activity. Meanwhile phenolic (rosmarinic acid), methoxy flavonoid (eupatorin, sinensetin, 5-hydroxy-6,7,3',4'-tetramethoxyflavone, salvigenin, 6-hydroxy-5,7,3'-trimethoxyflavone and 5,6,7,3'-tetramethoxy-4'-hydroxy-8-C-prenylflavone), diterpenes (orthosiphols, orthoarisins, neoorthosiphols, staminols, and staminolactones) and triterpenes (ursolic acid, oleanolic acid, betulinic acid, hydroxybetulinic acid, maslinic acid, $\alpha$-amyrin and $\beta$-amyrin) were identified as responsible compounds for the antioxidant activity.
\end{abstract}

Keywords: $\alpha$-glucosidase inhibitors, antioxidants, metabolomics, Orthosiphon stamineus

\section{ABSTRAK}

Tumbuhan merupakan salah satu sumber senyawa aktif yang potensial. Pendekatan metabolomik dilaporkan sebagai salah satu metode alternatif yang dapat mempercepat proses identifikasi komponen aktif dari tumbuhan. Pada penelitian ini, metode metabolomik berbasis FTIR digunakan untuk meng-identifikasi senyawa aktif dengan aktivitas penghambatan terhadap enzim a-glukosidase dan antioksidan pada ekstrak dan fraksi tanaman kumis kucing (OS). Profil kimia ekstrak metanolik dan fraksi heksana, kloroform, butanol, dan air OS diukur dengan FTIR. Ekstrak dan fraksi OS menunjukkan aktivitas penghambatan terhadap enzim a-glukosidase dengan nilai $I C_{50}$ berkisar $154,07 \pm 30,60-465,83 \pm 85,34 \mu \mathrm{g} / \mathrm{mL}$ dan aktivitas antioksidan dengan nilai IC 50 berkisar $7,41 \pm 0,02-19,35 \pm 0,09 \mu \mathrm{g} / \mathrm{mL}$. Fraksi butanol adalah fraksi dengan aktivitas penghambatan a-glukosidase tertinggi dan aktivitas antioksidan menengah dengan nilai IC 50 berturut-turut turut 154,07 $\pm 30,60$ $\mu \mathrm{g} / \mathrm{mL}$ dan $10,84 \pm 0,54 \mu \mathrm{g} / \mathrm{mL}$. Korelasi antara data aktivitas biologis dan komposisi kimia dianalisis dengan orthogonal projections to latent structures (OPLS). Berdasarkan nilai VIP (variable influence on projection), nilai koefisien dari model OPLS, dan pangkalan data IR senyawa yang telah teridentifikasi pada OS. Metoksi flavonoid (sinensitin dan 5,6,7,3'-tetrametoksi-4'-hidroksi-8-C-prenilflavon), diterpena (ortosifol, ortoarisin, neoortosifol, staminol, dan staminolakton), triterpena (asam ursolat, asam oleanolat, asam betulinat, asam hidroks ibetulinat, as am maslinat, $\alpha$-amirin dan $\beta$-amirin) diidentifikasi sebagai senyawa penghambat aktivitas enzim $\alpha$-glukosidase sedangkan fenolik (asam rosmarinat), flavonoid (eupatorin, sinensetin, 5-hidroksi6,7,3',4'-tetram etoks iflavon, salvigenin, 6-hidroksi-5,7,3'-trimetoksiflavon dan 5,6,7,3'-tetram etoksi-4'-hidroksi8-C-prenilflavon), diterpena (ortosifol, ortoaris in, neoortosifol, staminol, dan staminolakton), triterpena (asam ursolat, asam oleanolat, asam betulinat, asam hidroksibetulinat, asam maslinat, $\alpha$-amirin dan $\beta$-amirin) diidentifikasi sebagai senyawa antioksidan.

Kata kunci: a-glukosidase inhibitor, antioksidan, metabolomik, Orthosiphon stamineus

*Penulis Korespondensi: E-mail: nancy_dewi@ipb.ac.id 


\section{PENDAHULUAN}

Diabetes merupakan penyakit akibat kesalahan metabolisme glukosa yang disebabkan oleh kekurangan sekresi insulin, resistensi terhadap insulin maupun keduanya. Indonesia menempati posisi ketujuh negara dengan penderita diabetes terbanyak di dunia (IDF, 2013). Kumis kucing merupakan tanaman obat tradisional Indonesia yang digunakan untuk mengobati diabetes dengan cara menghambat aktivitas enzim pencernaan salah satunya enzim a-glukosidase (Mohamed et al., 2011; Mohamed et al., 2012). Selain anti hiperglikemik, tanaman kumis kucing kaya akan senyawa antioksidan (Akowuah et al., 2005) sehingga kumis kucing berpotensi pula untuk menurunkan risiko komplikasi diabetes akibat stres oksidatif (Baynes dan Thorpe, 1999). Dari sejumlah penelitian teridentifikasi 116 senyawa aktif dari tanaman kumis kucing yang berasal dari kelompok monoterpena, diterpena, triterpena, saponin, flavonoid, minyak atsiri, dan asam organik (Adnyana et al., 2013).

Salah satu metode yang dapat digunakan untuk mempercepat proses identifikasi komponen aktif dari ekstrak tanaman adalah metode metabolomik (Yuliana et al., 2011). Metabolomik merupakan analisis metabolit baik primer maupun sekunder secara menyeluruh di dalam suatu tanaman baik secara kuantitatif maupun kualitatif (Verpoorte et al., 2007). Pada proses identifikasi senyawa aktif dengan metode metabolomik ini, sampel kering tanaman diekstraksi menggunakan berbagai pelarut (difraksinasi), masing-masing fraksi kemudian dibagi dua; untuk uji bioaktifitas dan untuk uji profil kimia. Kedua data ini dianalisis dengan teknik analisis multivariat data (MVDA), misalnya orthogonal projections to latent structures (OPLS). OPLS dipilih pada penelitian ini karena teknik ini secara efektif mampu memisahkan variasi yang berkorelasi dengan aktivitas dengan variasi yang tidak berkorelasi dengan aktifitas sehingga memudahkan intepretasi data (Worley dan Powers, 2013).

Data profil kimia sampel dapat diperoleh dengan menggunakan berbagai teknik kromatografi maupun spektroskopi, misalkan fourier transform infrared (FTIR). Persiapan sampel yang cepat dan mudah, robust, dan non-destruktif menyebabkan teknik FTIR berpotensi untuk memperoleh data profil kimia pada penelitian ini (Pop et al., 2014). Metabolomik berbasis FTIR cukup sensitif digunakan untuk mengevaluasi perubahan metabolit buah pada berbagai musim (Hussain et al., 2009; Yusof et al., 2015) dan waktu panen (Yusof et al., 2015). Selain itu, metabolomik berbasis FTIR juga digunakan untuk mengevaluasi komposisi kimia secara kuantitatif untuk membedakan enam kultivar beri (Pop et al., 2014). Penelitian ini bertujuan mengidentifikasi senyawa aktif inhibitor a-glukosidase dan senyawa antioksidan melalui identifikasi gugus fungsi yang merupakan penanda dari senyawa aktif dengan menggunakan pendekatan metabolomik berbasis FTIR.

\section{BAHAN DAN METODE}

\section{Bahan}

Bahan yang digunakan pada penelitian ini adalah tanaman (daun, ranting, bunga) kumis kucing (Orthosiphon stamineus Benth) (Nagrak, Sukabumi).

\section{Persiapan sampel, ekstraksi dan fraksinasi kumis kucing}

Sebanyak $3 \mathrm{~kg}$ tanaman kumis kucing segar disortir dan dikeringkan dengan pengering kabinet pada suhu $45^{\circ} \mathrm{C}$ selama 8 jam. Tanaman kumis kucing kering dihaluskan menggunakan blender. Sebanyak $531 \mathrm{~g}$ serbuk tanaman kumis kucing dikemas dalam 3 plastik tertutup untuk 3 kali ekstraksi. Sampel disimpan di dalam freezer pada suhu $-20^{\circ} \mathrm{C}$ sampai dilakukan proses ekstraksi.

Tanaman kumis kucing (177 g) diekstraksi dengan menambahkan metanol $80 \%$ (Merck, USA) sebanyak dua kali volume serbuk kumis kucing, kemudian disonikasi dengan ultrasonic bath (Bransonic Ultrasonic Cleaner model 8510E MTH, Branson Ultrasonic Corporation, USA) selama 30 menit pada suhu ruang, disaring dan diambil filtratnya. Proses ekstraksi ini diulang dua kali. Hasil ekstraksi disatukan dan dikeringkan dengan evaporator putar (Butchi Rotavapor R-210, BÜCHII Labortechnik, Switzerland), dengan pompa vakum (Buchi B-169 vacum system, BÜCHII Labortechnik, Switzerland) pada suhu $40^{\circ} \mathrm{C}$ sampai $1 / 3$ volume awal (500 mL), sebanyak $100 \mathrm{~mL}$ dipisahkan (ekstrak ini selanjutnya disebut ekstrak metanolik). Sisa larutan ekstrak sebanyak $400 \mathrm{~mL}$ dikeringkan untuk kemudian difraksinasi sebagai berikut; ekstrak kering dilarutkan dalam $250 \mathrm{~mL}$ air, dimasukkan ke dalam labu pemisah dan ditambahkan $250 \mathrm{~mL}$ pelarut organik $(1: 1 \mathrm{v} / \mathrm{v})$. Pelarut organik yang ditambahkan berturut-turut adalah heksana (Merck, USA), kloroform (Merck, USA), dan n-butanol (Merck, USA). Tahapan proses ekstraksi dan fraksinasi ini diulang sebanyak 3 kali. Ekstrak dan fraksi dipekatkan dengan evaporator putar dan dikeringkan dengan pengering beku (Gamma 2-16 LSC, Martin Christ Gefriertrocknungsanlagen $\mathrm{GmbH}$ Germany).

\section{Uji penghambatan aktivitas enzim a-glukosidase}

Uji ini mengacu pada Sancheti et al. (2009). Sebanyak $50 \mu \mathrm{L}$ bufer fosfat $0,1 \mathrm{M} \mathrm{pH} \mathrm{6,9} \mathrm{(Sigma}$ Aldrich P0662 dan P3786), $25 \mu \mathrm{L}$ larutan $\mathrm{p}$ nitrofenill- $\alpha$-D-glukopiranosida (Sigma Aldrich N137 7) (dilarutkan dalam $0,1 \mathrm{M}$ larutan bufer fosfat $\mathrm{pH}$ 
6,9), ekstrak kumis kucing sebanyak $10 \mu \mathrm{L}$ dilarutkan dalam DMSO (Merck, USA) dan akarbosa (Glucobay®, PT. Bayer Indonesia) sebagai kontrol positif dilarutkan dalam akuabides, $25 \mu \mathrm{L} \alpha$ glukosidase $0,04 \mathrm{U} / \mathrm{mL}$ (Sigma Aldrich G3651) dalam larutan bufer $0,1 \mathrm{M} \mathrm{pH}$ 6,9 dicampurkan. Campuran ini diinkubasi pada suhu $37^{\circ} \mathrm{C}$ selama 30 menit. Reaksi dihentikan dengan menambahkan 100 $\mu \mathrm{L}$ larutan natrium karbonat 0,2 M (Sigma Aldrich 223530). Reaksi hidrolisis enzimatis diukur pada panjang gelombang $410 \mathrm{~nm}$ menggunakan microplate reader (Epoch Microplate Spectrophotometer, BioTek (B) Instruments Inc., USA). Pengujian dilakukan sebanyak 3 kali. Aktivitas inhibisi a-glukosidase dinyatakan sebagai \% inhibisi dan dihitung sebagai berikut:

$$
\% \text { inhibisi }=\frac{[(A B-A K B)-(A S-A K S)]}{(A B-A K B)} \times 100 \%
$$

$\mathrm{AB}=$ absorbans blanko, $\mathrm{AKB}=$ absorbans kontrol blanko, $A S=$ absorbans sampel, $A K S=$ absorbans kontrol sampel.

\section{Uji aktivitas antioksidan dengan DPPH}

Uji ini mengacu pada Salazar-Aranda et al. (2011). Sebanyak $500 \mu \mathrm{L}$ larutan ekstrak ditambahkan ke dalam $500 \mu \mathrm{L}$ larutan DPPH $125 \mu \mathrm{M}$ (Sigma Aldrich D9132) dalam EtOH (Merck, USA), diaduk dan didiamkan pada suhu ruang selama 30 menit. Penurunan absorbansi diukur menggunakan microplate reader (Epoch Microplate Spectrophotometer, BioTek $\AA$ Instruments Inc., USA) pada gelombang $517 \mathrm{~nm}$. Kuersetin (Sigma Aldrich 337951) digunakan sebagai kontrol positif.

$$
\% \text { aktivitas antioksidan }=\frac{[(A B-A K B)-(A S-A K S)]}{(A B-A K B)} \times 100 \%
$$

$\mathrm{AB}=$ absorbansi blanko, $\mathrm{AKB}=$ absorbansi kontrol blanko, $A S=$ absorbansi sampel, $A K S=$ absorbansi kontrol sampel.

\section{Uji profil kimia tanaman kumis kucing dengan FTIR}

Uji profil kimia sampel diukur dengan FTIR (Tensor 37, Bruker Optik GmbH, Germany) dilengkapi detektor DTGS (deuterated triglycine sulphate) menggunakan teknik pelet $\mathrm{KBr}$ pada mode absorbans. Spektrum diperoleh kemudian diproses dengan peranti lunak OPUS versi 4.2. Perlakuan pendahuluan berupa pemrosesan sinyal dilakukan pada area puncak spektra FTIR ekstrak dan fraksi yang diperoleh dari hasil pengukuran yang diskalakan terhadap puncak total dan dikurangi menjadi daerah terintegrasi dengan lebar sama (bilangan gelombang $2 \mathrm{~cm}^{-1}$ ) menggunakan peranti lunak XLSTAT versi 2012.

\section{Analisis data}

Pada penelitian ini spektrum FTIR merepresentasikan profil kimia ekstrak dan fraksi kumis kucing yang kemudian digunakan sebagai matriks data $X$, sedangkan aktivitas (penghambatan enzim a-glukosidase atau antioksidan merupakan matriks data Y). Spektrum dibuat turunannya menggunakan metode multi-plicative signal correction (MSC). Data dianalisis dengan orthogonal projection to latent structures (OPLS) menggunakan perangkat lunak SIMCA-P versi 13.0 dengan penskalaan pareto. Model di-deskripsikan dengan kriteria ketepatan model $\left(R^{2} Y\right)$ dan ketepatan prediksi $\left(Q^{2} Y\right)$. Model kemudian divalidasi dengan CV ANOVA dan uji permutasi.

\section{HASIL DAN PEMBAHASAN}

\section{Aktivitas penghambatan a-glukosidase ekstrak dan fraksi kumis kucing \\ Hasil uji aktivitas penghambatan enzim $\alpha$ -} glukosidase oleh ekstrak dan fraksi kumis kucing dapat dilihat pada Gambar 1. Ekstrak metanol, fraksi kloroform dan butanol menunjukkan aktivitas penghambatan terhadap enzim $\alpha$-glukosidase akan tetapi aktivitas penghambatan terkuat diperoleh dari fraksi butanol. Namun demikian aktivitas penghambatan oleh fraksi butanol masih lebih rendah dibandingkan dengan kontrol positif akarbosa.

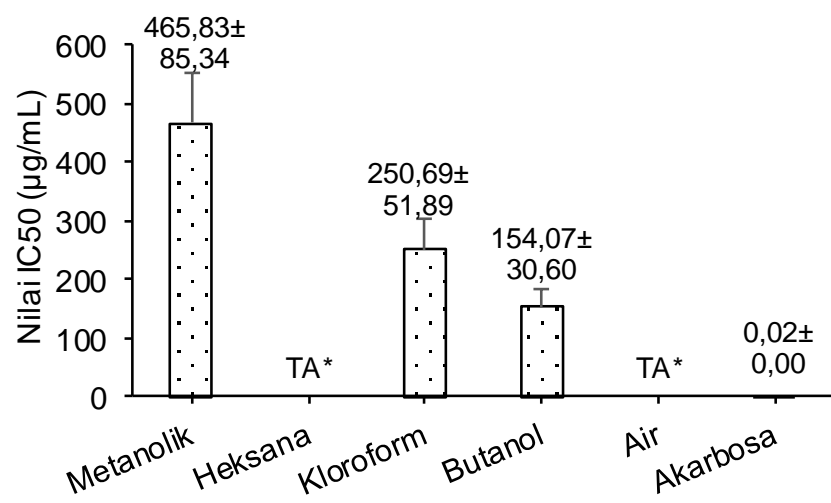

Keterangan: *Tidak aktif pada konsentrasi tertinggi diujikan yaitu $476 \mu \mathrm{g} / \mathrm{mL}$

Gambar 1. Aktivitas penghambatan enzim $\alpha$ glukosidase oleh ekstrak dan fraksi kumis kucing

Ekstrak etanol daun kumis kucing dilaporkan memiliki aktivitas penghambatan terhadap enzim $\alpha$ glukosidase dengan $I_{50}$ sebesar $4,63 \mathrm{mg} / \mathrm{mL}$ (Mohamed et al., 2012) lebih besar dibandingkan dengan nilai $\mathrm{IC}_{50}$ yang diperoleh dari hasil penelitian yaitu sebesar sebesar $465,83 \mu \mathrm{g} / \mathrm{mL}$. Perbedaan asal geografis tempat tumbuh, jenis pelarut dan bagian tanaman yang yang digunakan mem- 
pengaruhi kandungan bioaktif sehingga dapat menyebabkan perbedaan aktifitas biologis dari tanaman kumis kucing (Rafi et al., 2015; Akowuah et al., 2005). Penggunaan metanol dan air (aquaeos methanol) sebagai pelarut untuk ekstraksi tanaman kumis kucing diketahui mampu mengekstrak lebih banyak senyawa aktif dan memiliki kandungan total fenolik lebih tinggi dibandingkan pelarut lainnya (Abdelwahab et al., 2011). Tanaman kumis kucing kaya akan kandungan senyawa fenolik termasuk flavonoid (Sriplang et al., 2007). Beberapa literatur menyatakan senyawa penghambat aktivitas $\alpha$ glukosidase termasuk dalam kelompok ini (Kwon et al., 2008; Shobana et al., 2009).

Fraksi kloroform kumis kucing diketahui mengandung terpenoid dan flavonoid termasuk sinensitin (Mohamed et al., 2011). Sinensitin merupakan senyawa metoksi flavonoid larut kloroform dengan aktivitas anti $\alpha$-glukosidase kuat $\left(\mathrm{IC}_{50} 0,66\right.$ $\mathrm{mg} / \mathrm{mL}$ ) (Mohamed et al., 2012). Aktivitas penghambatan a-glukosidase oleh fraksi butanol kumis kucing belum pernah dilaporkan akan tetapi senyawa glikosida dan flavonoid dengan aktivitas anti a-glukosidase kuat diisolasi dari fraksi butanol herbal Gynostemma pentaphyllum (Yang et al., 2013). Kumis kucing dilaporkan mengandung senyawa glikosida termasuk saponin (Siddiqui et al., 2009).

\section{Aktivitas antioksidan ekstrak dan fraksi kumis kucing}

Pada Tabel 1 dapat diamati aktivitas antioksidan ekstrak dan fraksi kumis kucing. Aktivitas antioksidan pada penelitian ini lebih tinggi pada fraksi dan ekstrak yang semipolar dan polar (air, butanol, dan metanolik) dibandingkan fraksi nonpolar (kloroform dan heksana) akan tetapi aktivitas yang diperoleh lebih rendah dibandingkan kuersetin sebagai kontrol positif. Perbedaan polaritas pelarut ekstraksi digunakan yaitu $\mathrm{MeOH} 80 \%$ dengan $\mathrm{MeOH} 60 \%$ dapat menjadi salah satu penyebab perbedaan nilai $I_{50}$ yang diperoleh dari penelitian ini dengan Abdelwahab et al. (2011). Kemampuan solven yang digunakan dalam melarutkan senyawa fenolik menentukan aktivitas antioksidan. Senyawa marker terpolar yaitu asam rosmarinat dilaporkan tertinggi kandungannya pada solven $\mathrm{MeOH} 50 \%$ secara signifikan dibandingkan $\mathrm{MeOH} 100 \%$. Asam rosmarinat merupakan antioksidan terkuat dibandingkan marker lainnya (Akowuah et al., 2005). Khamsiah et al. (2006) melaporkan perbedaan tempat tumbuh tanaman kumis kucing yang juga dapat menjadi penyebab perbedaan kandungan senyawa fenolik dan aktivitas antioksidan. Fenolik merupakan salah satu kelompok penting senyawa aktif kumis kucing yang berkontribusi terhadap aktivitas antioksidan (Akowuah et al., 2004).
Tabel 1. Perbandingan aktivitas antioksidan oleh ekstrak dan fraksi kumis kucing yang diperoleh pada penelitian ini dengan literatur

\begin{tabular}{lcc}
\hline \multirow{2}{*}{$\begin{array}{c}\text { Ekstrak atau } \\
\text { Fraksi }\end{array}$} & \multicolumn{2}{c}{$\mathrm{C}_{50}(\mu \mathrm{g} / \mathrm{mL})$} \\
\cline { 2 - 3 } & Hasil Penelitian & $\begin{array}{c}\text { Abdelwahab } \\
\text { et al., 2011 }\end{array}$ \\
\hline Metanolik & $7,41 \pm 0,02$ & 16,66 \\
Heksana & TA $^{*}$ & 126,2 \\
Kloroform & TA $^{*}$ & 31,25 \\
Butanol & $10,84 \pm 0,54$ & 13,56 \\
Air & $19,35 \pm 0,09$ & 23,0 \\
Kuersetin & $5,46 \pm 0,00$ & - \\
\hline
\end{tabular}

Keterangan: *Tidak aktif pada konsentrasi yang tertinggi diujikan yaitu $25 \mu \mathrm{g} / \mathrm{mL}$, ** kontrol positif

Dari empat marker yaitu sinensetin (SEN), eupatorin (EUP) and 3'-hidroksi-5,6,7,4'-tetrametoksiflavon (TMF) dan asam rosmarinik (RA) fraksi kloroform tinggi akan kandungan SEN dan EUP (Akouwah et al., 2005). Oleh karena gugus O-metil pada SEN, EUP dan TMF senyawa-senyawa ini bersifat lipofilik sehingga memungkinkan terkandung dalam jumlah besar dalam ekstrak non polar. Fraksi kloroform dan heksan tinggi akan kandungan total flavonoid (Abdelwahab et al., 2011). Diantara solven-solven yang digunakan kloroform dan heksan merupakan solven paling tidak polar sehingga memungkinkan melarutkan sebagian besar senyawa flavonoid lipofilik. Aktivitas antioksidan tinggi pada fraksi dan ekstrak semipolar dan polar dapat disebabkan salah satunya oleh senyawa RA yang diketahui merupakan senyawa polar. Tidak hanya itu senyawa gula diduga juga dapat berperan sebagai antioksidan mengingat penstabilan aktivitas radikal bebas oleh antioksidan disebabkan oleh kemampuannya mendonorkan hidrogen (Akowuah et al., 2005).

\section{Korelasi profil komposisi kimia dan bioaktivitas ekstrak dan fraksi kumis kucing dengan OPLS}

Pada prinsipnya OPLS mencoba mengorelasikan dua jenis data matriks, yaitu data berupa komposisi kimia sampel $(X)$ dan data aktivitas sampel $(Y)$. Terdapat beberapa keluaran OPLS yang dapat digunakan untuk menafsir data di antaranya score plot, plot Y-related coefficient dan plot variable influence on projection (VIP). Untuk mengidentifikasi gugus fungsi senyawa aktif, plot VIP digunakan sebagai parameter sinyal $x$ penting terhadap data $Y$ sedangkan plot $Y$-related coefficient digunakan guna mempelajari sinyal yang berkorelasi positif dengan mariks data $Y$ (bioaktivitas). VIP hanya memberikan nilai korelasi positif untuk semua sinyal sedangkan plot $Y$-related coefficient dapat memberikan nilai korelasi baik positif dan negatif (Eriksson et al., 2006). Sinyal yang dipilih adalah sinyal yang berkorelasi positif dan bernilai VIP>0,5. 
Profil kimia senyawa penghambat aktivitas enzim a-glukosidase

Score plot pada OPLS digunakan untuk mengelompokkan sampel berdasarkan karakteristik data matriks $Y$ (aktivitas penghambatan enzim $\alpha$ glukosidase). Pemisahan yang baik antara sampel dengan aktivitas rendah dan sampel dengan aktivitas tinggi menunjukkan bahwa OPLS dapat digunakan lebih lanjut untuk mengidentifikasi gugus fungsi senyawa aktif. Pada Gambar 2 terlihat fraksi aktif dan fraksi tidak aktif terpisah dengan baik sehingga proses identifikasi gugus fungsi senyawa aktif dengan OPLS dapat dilakukan lebih lanjut. Ketepatan model OPLS dapat dilihat dari nilai $R^{2} Y$ dan $Q^{2} Y$. Nilai $R^{2} Y$ merupakan jumlah variabel $Y$ yang dapat dijelaskan oleh model dan peninjauan kecocokan model. $Q^{2} Y$ adalah hasil validasi silang dan pengukuran kuantitatif antara hasil prediksi dengan data yang sebenarnya. Nilai $R^{2} Y$ diperoleh pada model ini sebesar 0,76 sedangkan nilai $Q^{2} Y$ sebesar 0,59. Pada model OPLS ini kedua nilai tersebut $>0,5$ sehingga tergolong model yang baik (Eriksson et al., 2006).

OPLS cenderung memaksakan kecocokan model dengan data (over-fit) sehingga dibutuhkan tahapan validasi untuk memastikan keandalan (reliability) dari model (Worley dan Powers, 2013). Nilai $p$ yang menjadi patokan pada metode validasi CV ANOVA yang diperoleh pada penelitian ini sebesar 0,03 , lebih kecil dari nilai maksimum yang diterima, yaitu $P<0,05$ sehingga model dianggap memiliki reabilitas yang baik (Eriksson et al., 2008). Selain itu, test permutasi juga dilakukan untuk mengetahui seberapa besar terjadinya korelasi yang tidak disengaja akibat jumlah sampel yang kecil dengan variabel yang berjumlah besar (Lindgren et al., 1996). Model yang valid seharusnya memiliki nilai intersep $R^{2}$ dan $Q^{2}$ pada sumbu $Y$ berturut-turut tidak lebih dari 0,3-0,4 (Eriksson et al., 2006). Nilai intersep $R^{2}$ dan $Q^{2}$ yang diperoleh pada model ini berturut-turut adalah 0,26 dan $-0,94$.

Pada Gambar 3 diketahui ada lima area puncak bilangan gelombang yang berkorelasi positif terhadap aktivitas penghambatan enzim $\alpha$-glukosidase yaitu Area A (2844-2978 $\left.\mathrm{cm}^{-1}\right)$, Area B (1675-1758 $\left.\mathrm{cm}^{-1}\right)$, Area C (1161-1302 $\left.\mathrm{cm}^{-1}\right)$, Area D (934-980 $\left.\mathrm{cm}^{-1}\right)$, dan Area E (480-399 $\left.\mathrm{cm}^{-1}\right)$. Area Puncak A, B, $C$ dan $D$ dipilih untuk diidentifikasi lebih lanjut karena pada puncak tersebut terdapat sinyal penanda senyawa aktif penting terhadap aktivitas penghambatan terhadap a-glukosidase. Pita serapan Area A (2845-2977 cm $\left.\mathrm{cm}^{-1}\right)$ mengindikasikan vibrasi ulur asimetri dan simetri gugus fungsi dari grup metilena $\left(\mathrm{CH}_{2}\right.$ dan $\left.\mathrm{CH}_{3}\right)$, turunan metoksi dan $\mathrm{C}-\mathrm{H}$ (aldehid) termasuk cis ikatan rangkap dan hidroksil (Saidan et al., 2015). Area B (1676-1755 $\mathrm{cm}^{-1}$ ) mengindikasikan gugus karbonil sedangkan Area C (1162-1301 $\left.\mathrm{cm}^{-1}\right)$ mengindikasikan gugus ulur $\mathrm{C}-\mathrm{O}$ dan $\mathrm{OH}$. Area $\mathrm{D}\left(935-979 \mathrm{~cm}^{-1}\right)$ mengindikasikan keberadaan vinil atau pita tekuk $\mathrm{C}-\mathrm{H}$ dari senyawa aromatik (Silva et al., 2014; Pop et al., 2014).

\section{Penanda senyawa penghambat aktivitas enzim a-glukosidase}

Pita serapan serapan sempit dan tajam pada bilangan gelombang $2924 \mathrm{~cm}^{-1}$ dan $2854 \mathrm{~cm}^{-1}$ yang mencirikan senyawa metoksi flavonoid (Rafi et al., 2015).

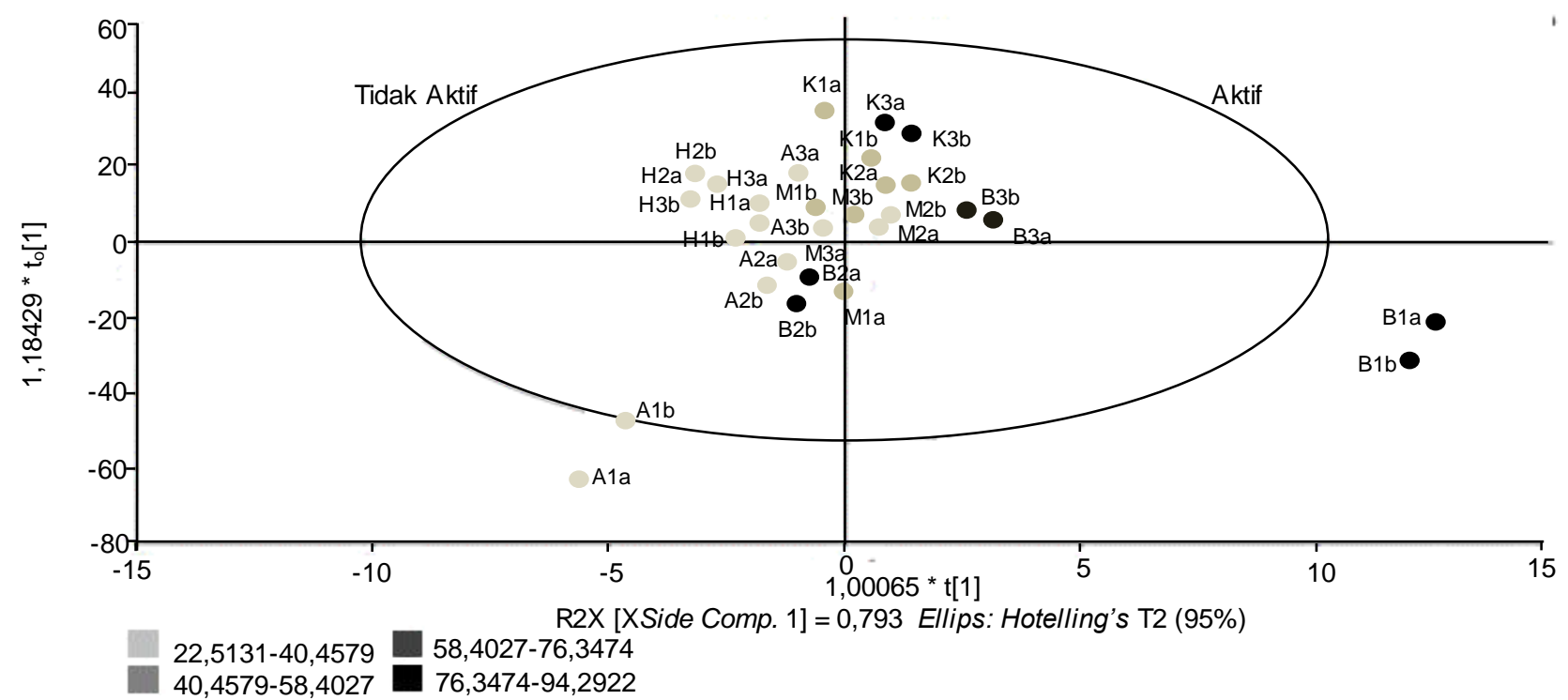

Gambar 2. OPLS score plot aktivitas penghambatan a-glukosidase oleh ekstrak dan fraksi kumis kucing. Tiap sampel diwakili oleh lingkaran dengan variasi warna abu-abu ke hitam mewakili sampel dengan aktivitas rendah ke aktivitas tinggi. Sumbu dan ordinat plot menunjukkan skor OPLS untuk setiap sampel 


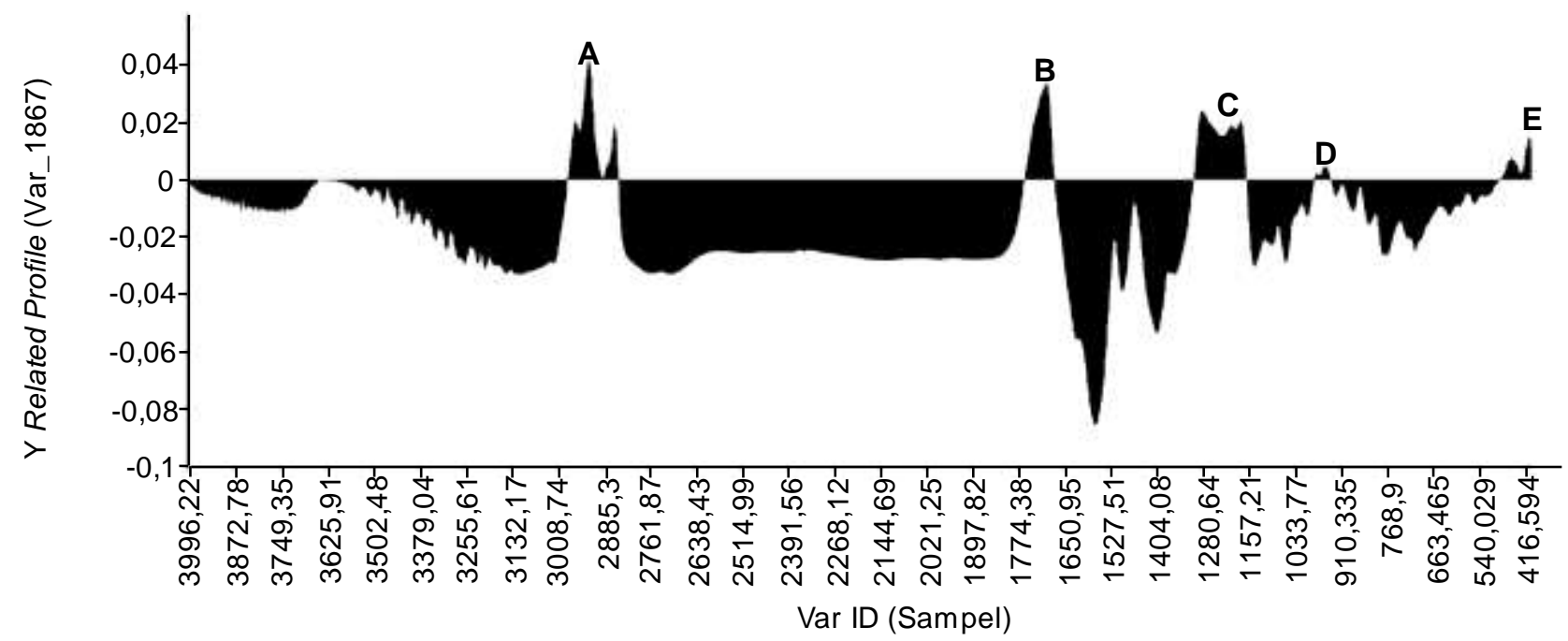

Gambar 3. Plot $Y$-related coefficient ekstrak dan fraksi kumis kucing. Area A $\left(2845-2977 \mathrm{~cm}^{-1}\right)$, Area B $\left(1676-1755 \mathrm{~cm}^{-1}\right)$, Area C $\left(1162-1301 \mathrm{~cm}^{-1}\right)$, Area D $\left(935-979 \mathrm{~cm}^{-1}\right)$, dan Area E $\left(480-399 \mathrm{~cm}^{-1}\right)$ adalah puncak-puncak yang menunjukkan korelasi positif dengan aktivitas penghambatan $\alpha$ glukosidase

Hasil analisis OPLS mengindikasikan senyawa sinensitin dan 5,6,7,3'-tetrametoksi-4'-hidroksi-8-Cprenilflavon (Hossain dan Rahman, 2015) memiliki aktivitas penghambatan terhadap enzim a-glukosidase. Flavonoid kumis kucing umumnya terdapat dalam bentuk termetoksilasi dan larut kloroform, bilangan gelombang penanda gugus fungsi aktif flavonoid seperti $\mathrm{OCH}_{3}\left(2928 \mathrm{~cm}^{-1}\right.$ dan $\left.2857 \mathrm{~cm}^{-1}\right)$, C-O (1234-1284 cm $\left.{ }^{-1}\right)$, C-O dan C-OH (1173-1176 $\mathrm{cm}^{-1}$ ) dan dan pita tekuk $\mathrm{C}-\mathrm{H}$ dari senyawa aromatik (913-997 $\mathrm{cm}^{-1}$ ) pada penelitian ini dapat diamati pada spektrum fraksi aktif kloroform. Perbedaan antara bilangan gelombang yang diperoleh pada literatur dengan pada spektra kemungkinan disebabkan oleh senyawa yang diukur pada literatur merupakan senyawa murni. Pengukuran contoh dalam bentuk campuran memungkinkan terjadi tumpang tindih puncak gugus fungsi penanda senyawa aktif dalam spektra ekstrak maupun fraksi (Stehfest et al., 2004). Rangkuman hasil analisis karakteristik IR seluruh senyawa yang diidentifikasi memiliki aktivitas penghambatan terhadap a-glukosidase berupa nilai VIP berkisar 0,00-1,63 dan memiliki nilai $Y$-related coefficient positif dapat dilihat pada Tabel 2. Nilai VIP $\geq 0,5$ dianggap relevan sedangkan nilai VIP>1 sangat relevan (GalindoPrieto et al., 2014). Sinensitin dengan gugus fungsi dari grup metoksi, asam karboksilat, cincin aromatik dan heteroaromatik, metil, hidroksi fenolik, C-O, dan ujung metilena merupakan salah satu senyawa yang diketahui memiliki aktivitas penghambatan terhadap a-glukosidase (Hossain dan Rahman, 2015; Mohamed et al., 2012). Hasil berbeda dikemukakan oleh Damsud et al. (2014) yang mengisolasi 4 flavonoid yaitu sinensetin, salvigenin, tetrametilskutellarein dan 3,7,4'-tri-O-metilkaempferol. Dari empat flavonoid tersebut tetrametilskutellarein dan 3,7,4'-tri-O-metilkaempferol menghambat a-glukosidase khamir dengan $\mathrm{IC}_{50}$ berturut-turut sebesar 6,34 $\mathrm{mM}$ dan $0,75 \mathrm{mM}$. Diketahui bahwa subtitusi gugus metoksil pada flavonoid menurunkan aktivitas penghambatan a-glukosidase (Gao et al., 2004; Asghari et al., 2015). Sinensetin dengan struktur kimia terdapat lima gugus metoksi merupakan senyawa flavonoid dengan subtitusi gugus metoksi terbanyak dari tanaman kumis kucing. Selain itu keberadaan gugus $\mathrm{OH}$ dan $\mathrm{C}=\mathrm{O}$ diduga memiliki kecenderungan meningkatkan aktivitas penghambatan a-glukosidase oleh flavonoid. Kemampuan gugus fungsi $\mathrm{C}=\mathrm{O}$ diduga lebih baik dibandingkan gugus fungsi $\mathrm{OH}$ dalam membentuk ikatan hidrogen pada sisi aktif enzim yang merupakan salah satu mekanisme penghambatan enzim a-glukosidase oleh senyawa bioaktif (Asghari et al., 2015; Uddin et al., 2012).

Senyawa diterpen ditandai dengan adanya pita serapan gugus hidroksil pada bilangan gelombang 3500-3480 $\mathrm{cm}^{-1}$, ester karbonil pada bilangan gelombang $1270-1150 \mathrm{~cm}^{-1}$, dan fenil pada bilangan gelombang $1600 \mathrm{~cm}^{-1}$ dan $1420 \mathrm{~cm}^{-1}$ (Sim et al., 2004). Senyawa diterpen dapat diisolasi dari fraksi kloroform (Awale et al., 2002; Awale et al., 2003). Pada spektrum aktif fraksi kloroform dapat diamati gugus fungsi aktif penanda diterpen yaitu hidroksil pada bilangan gelombang $3396-3420 \mathrm{~cm}^{-1}$ dan ester karbonil pada bilangan gelombang $1113-1284 \mathrm{~cm}^{-1}$. Berdasarkan hasil identifikasi gugus fungsi penanda senyawa penghambat aktivitas enzim a-glukosidase mengindikasikan senyawa dari kelompok diterpen tipe isopimaran yaitu ortosifol F-J (Tezuka et al., 2000), ortoarisin A, ortoarisin B, ortoarisin C, ortoarisin $D$, ortoarisin $E$, ortoarisin $F$, ortoarisin $G$ (Di et al., 2013) sebagai senyawa penghambat 
aktivitas enzim a-glukosidase. Walaupun belum ada laporan aktivitas senyawa isopimaran diterpen dari kumis kucing tetapi isopimaran diterpen baru $5 R$, $6 S, 10 S, 11 R, 13 R$ and $14 S$ dan isopimaran diterpen teridentifikasi 11-deoksidiaportein $A$ dari kapang laut Epicoccum sp. HS-1 dilaporkan memiliki aktivitas penghambatan terhadap enzim a-glucosidase dengan nilai $\mathrm{IC}_{50}$ berturut-turut 4,6 $\mu \mathrm{M}$ dan 11,9 $\mu \mathrm{M}$ (Xia et al., 2015).

Senyawa penghambat aktivitas enzim a-glukosidase juga diidentifikasi dari kelompok diterpen tipe isopimaran teroksigenasi yaitu ortosifol $\mathrm{O}$, ortosifol $\mathrm{P}$, ortosifol $\mathrm{Q}$, dan noortosifonolida $\mathrm{A}$ (Awale et al., 2002), kelompok diterpen tipe isopimaran teroksigenasi tinggi ortosifol $A$, ortosifol $B$, ortosifol $U$, ortosifol $\mathrm{V}$, ortosifol $\mathrm{W}$, ortosifol $\mathrm{X}$, ortosifol $\mathrm{Y}$ dan ortosifol Z (Masuda et al., 1992; Awale et al., 2003), kelompok diterpen tipe isopimaran termigrasi yaitu neoortosifol A dan neoortosifol B (Ohashi et al., 2000), dan senyawa ortoarisin $H$ dari kelompok diterpen tipe sekoisopimaran (Di et al., 2013). Diterpen tipe isopimaran teroksigenasi tinggi ortosifol A yang dikarakterisasi berdasarkan data spektroskopi secara selektif menghambat enzim maltase dengan nilai $I_{50}$ sebesar $6,54 \mathrm{mM}$. Stud lebih lanjut ortosifol A menunjukkan bahwa aktivitas penghambatan fungsi maltase terjadi secara tidak kompetitif (Damsud et al., 2014). Diterpen tipe sekoisopimaran dari Salvia cinnabarina diketahui memiliki aktivitas antipasmodik (Capasso et al., 2004) dan mutagenik (Di Sotto et al., 2009) akan tetapi aktivitas penghambatan terhadap enzim $\alpha$ glukosidase belum pernah dilaporkan. Senyawa penghambat aktivitas enzim a-glukosidase diidentifikasi dari kelompok diterpen tipe staminan adalah staminol A, staminol $B$, staminolakton A, staminolakton B, norstaminol A (Tezuka et al., 2000) dan ortoarisin I (Di et al., 2013).

Asam ursolat, asam oleanolat, asam betulinat, asam hidroksibetulinat, $\alpha$-amirin, $\beta$-amirin, asam maslinat (Hossain dan Ismail, 2013) merupakan senyawa triterpen yang diidentifikasi dari gugus fungsi penanda senyawa penghambat aktivitas enzim $\alpha$-glukosidase yang diduga berkontribusi terhadap aktivitas penghambatan enzim a-glukosidase. Asam maslinat dan asam oleanolat dari ekstrak etil asetat daun Lagerstroemia speciosa dilaporkan memiliki aktivitas penghambatan terhadap enzim $\alpha$ glukosidase dengan $\mathrm{IC}_{50}$ berturut-turut $5,52 \mathrm{~g} / \mathrm{mL}$ dan 6,29 g/mL (Hou et al., 2009). Lebih lanjut senyawa triterpen penghambat aktivitas enzim $\alpha$ glukosidase asam ursolat $\left(\mathrm{IC}_{50} 47,6 \mu \mathrm{M}\right)$ dan asam betulinat $\left(\mathrm{IC}_{50} \quad 14,0 \mu \mathrm{M}\right)$ diisolasi dari apel emas merah (Malus domestica) (He et al., 2014). Asam ursolat dan asam oleanolat sebagai senyawa yang menghambat aktivitas enzim a-glukosidase secara tidak kompetitif dengan nilai $I_{50}$ berturut-turut 39,0 dan 35,0 mM juga dilaporkan dari bunga Punica granatum L. (Salah et al., 2014). Asam hidroksibetulinat belum pernah dilaporkan memiliki aktivitas penghambatan terhadap enzim $\alpha$-glukosidase akan tetapi pentasiklik triterpen asetat $3 \beta$-asetoksi-16 $\beta$ asam hidroksibetulinat dari tanaman Fagara tessmannii Engl. menunjukkan aktivitas penghambatan yang signifikan terhadap enzim $\alpha$-glukosidase $\left(\mathrm{IC}_{50}\right.$ 7,6 $\mu \mathrm{M})$ (Mbaze et al., 2007). Secara in vivo a-amirin dan $\beta$-amirin menunjukkan aktivitas antihiperglikemik pada konsentrasi 10, 30 dan 100 mg/kg terhadap mencit (Santos et al., 2012). Aktivitas antihiperglikemik ini dapat diakibatkan salah satunya oleh aktivitas penghambatan terhadap enzim $\alpha$ glukosidase. $\beta$-amirin dari Memecylon umbellatum Burm. F dilaporkan memiliki aktivitas penghambatan terhadap enzim a-glukosidase secara signifikan pada konsentrasi 10,0 mM (Sridevi et al., 2015).

\section{Profil kimia senyawa antioksidan}

Score plot pada OPLS digunakan untuk mengelompokkan sampel berdasarkan karakteristik data matriks Y (aktivitas antioksidan). Pada Gambar 4 terlihat fraksi aktif dan fraksi tidak aktif terpisah dengan baik sehingga memungkinkan penggunaan OPLS dalam mengidentifikasi gugus fungsi senyawa aktif lebih lanjut. Nilai $R^{2} Y$ dan $Q^{2} Y$ diperoleh berturut-turut sebesar 0,82 dan 0,59. Hasil validasi silang CV ANOVA diperoleh 0,03 sehingga secara statistik metode ini tergolong valid (Eriksson et al., 2008). Dari hasil permutasi diperoleh nilai intersep $R^{2}$ dan $Q^{2}$ berturut-turut adalah 0,29 dan $-0,95$ sehingga dapat disimpulkan bahwa model OPLS ini cukup valid. Pada Gambar 5 terdapat lima area puncak dengan bilangan gelombang yang berkorelasi positif terhadap aktivitas antioksidan yaitu Area A (3020-3649 cm $\left.\mathrm{cm}^{-1}\right)$, Area B (1600-1635 cm $\left.\mathrm{cm}^{-1}\right)$, Area C (1519-1598 cm $\mathrm{cm}^{-1}$, Area D $\left(1380-1409 \mathrm{~cm}^{-1}\right)$, dan Area E (408-430 $\left.\mathrm{cm}^{-1}\right)$. Selain Area E (408-430 $\mathrm{cm}^{-1}$ ), puncak-puncak yang korelasi positif dengan aktivitas antioksidan digunakan untuk identifikasi senyawa aktif lebih lanjut karena terdapat sinyal penanda senyawa aktif penting $(\mathrm{VIP}>0,5)$. Gugus fungsi $\mathrm{OH}$ direpresentasikan oleh bilangan gelombang pada Area A (3020-3649 $\left.\mathrm{cm}^{-1}\right)$ sedangkan Area B (1600-1635 cm $\mathrm{cm}^{-1}$ ), Area C (1519-1598 $\left.\mathrm{cm}^{-1}\right)$ mengindikasikan keberadaan cincin aromatik. Area D (1380-1409 mengindikasikan pita tekuk $\mathrm{CH}_{3}$ (Pop et al., 2014; Saidan et al., 2015).

\section{Penanda senyawa antioksidan}

Pita ulur dari grup fenil $(\mathrm{C}=\mathrm{C})$ pada bilangan gelombang $1609-1608 \mathrm{~cm}^{-1}$ dan bilangan gelombang 1516-1516 $\mathrm{cm}^{-1}$ merupakan karakteristik IR tipikal senyawa aromatik yang dapat mengindikasikan keberadaan senyawa fenolik (Silva et al., 2014). Pada spektra karakteristik IR senyawa fenolik berupa pita ulur dari grup fenil $(\mathrm{C}=\mathrm{C})$ berada pada bilangan gelombang $1602-1608$ dan $1522-2527 \mathrm{~cm}^{-}$ 


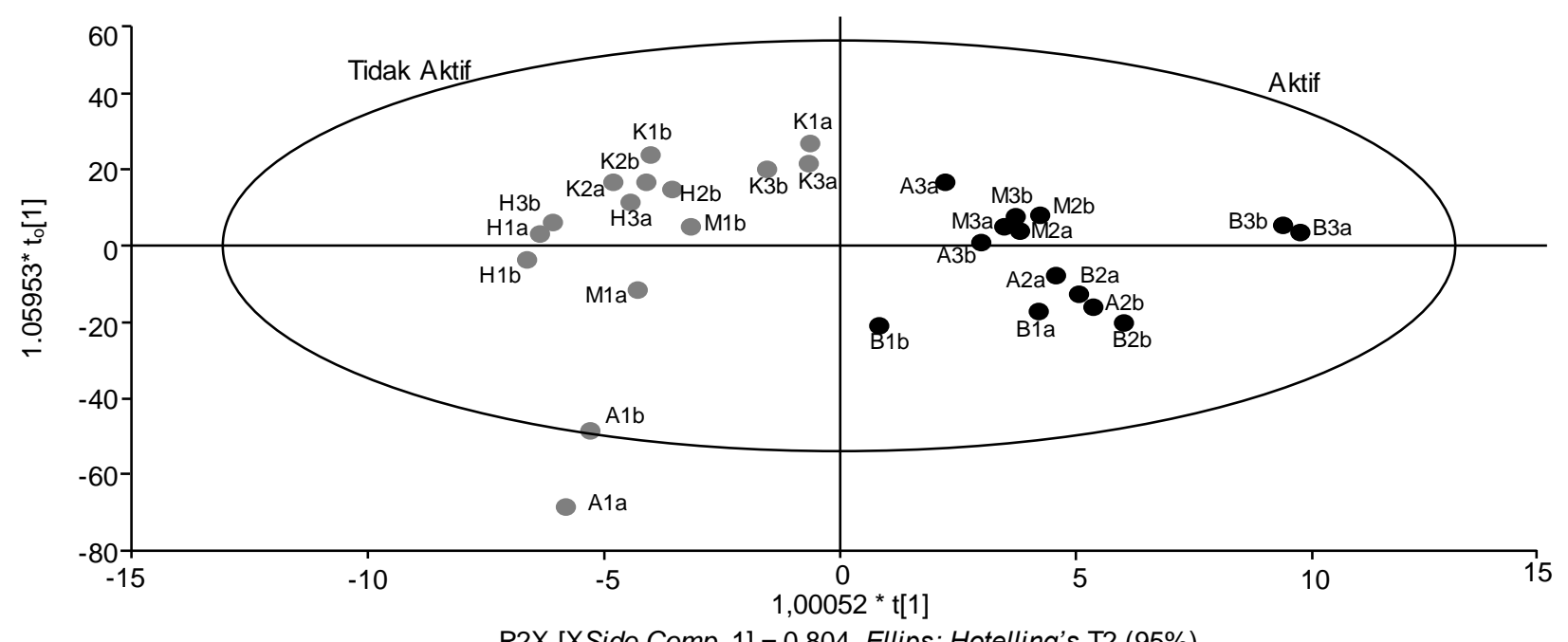

$17,9153-57,6217$

$57,6217-97,3282$

Gambar 4. OPLS score plot antioksidan ekstrak dan fraksi kumis kucing. Tiap sampel diwakili oleh lingkaran dengan variasi warna abu-abu ke hitam mewakili sampel dengan aktivitas rendah ke aktivitas tinggi. Sumbu dan ordinat plot menunjukkan skor OPLS untuk setiap sampel

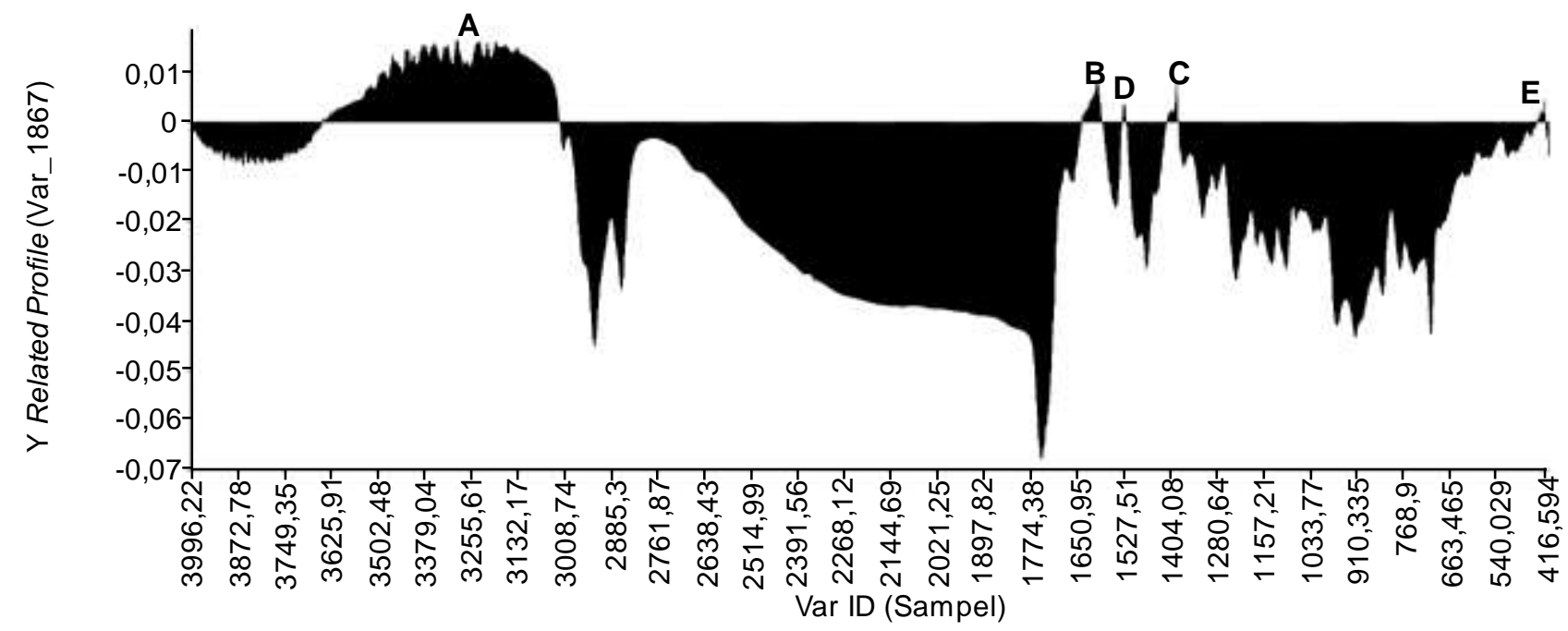

Gambar 5. Plot $Y$-related coefficient ekstrak dan fraksi kumis kucing. Area A $\left(3020-3649 \mathrm{~cm}^{-1}\right)$, Area B $\left(1600-1635 \mathrm{~cm}^{-1}\right)$, Area C $\left(1519-1598 \mathrm{~cm}^{-1}\right)$, Area D $\left(1380-1409 \mathrm{~cm}^{-1}\right)$, dan Area E $(408-430$ $\mathrm{cm}^{-1}$ ) adalah puncak-puncak yang menunjukkan korelasi positif dengan aktivitas antioksidan

Asam rosmarinat yang merupakan senyawa fenolik polar turunan asam kafeat dengan gugus fungsi cincin aromatik, $\mathrm{C}-\mathrm{H}$ aromatik, grup fenol dan karboksilat diketahui memiliki kontribusi kuat terhadap aktivitas antioksidan (Stehfest et al., 2004; Hunaefi et al., 2012). Rangkuman hasil analisis karakteristik IR seluruh senyawa yang diidentifikasi memiliki aktivitas antioksidan berupa nilai VIP berkisar 0,01-0,67 dan memiliki nilai $Y$-related coefficient positif dapat dilihat pada Tabel 3. VIP merupakan parameter yang digunakan untuk mengukur secara kumulatif pengaruh variabel $X$ pada model yang mana nilai $V I P \geq 0,5$ dianggap relevan (Galindo-Prieto et al., 2014). Gugus fungsi
$\mathrm{OH}_{-1}\left(>3000 \mathrm{~cm}^{-1}\right)$ dan cicin aromatik $(>1500-1600$ $\mathrm{cm}^{-1}$ ) bernilai VIP berturut-turut $0,15-0,67$ dan $0,09-$ 0,33 memiliki peranan penting terhadap aktivitas antioksidan. Kedua gugus fungsi ini sangat umum ditemukan terutama jika contoh yang diukur dalam bentuk campuran sehingga tumpang tindih gugus fungsi $\mathrm{OH}$ dan cincin aromatik senyawa aktif dengan senyawa tidak aktif sangat mungkin terjadi. Kumis kucing diketahui tinggi akan kandungan senyawa fenolik salah satunya flavonoid. Berdasarkan hasil identifikasi gugus fungsi penanda senyawa antioksidan mengindikasikan senyawa-senyawa metoksi flavonoid dan flavonoid terprenilasi berikut memiliki aktivitas antioksidan antara lain eupatorin, sinensitin, 
5-hidroksi-6,7,3',4'-tetrame-toksflavon, salvegenin, 6-hidroksi-5,7,3'-trimetok-siflavon, dan 5,6,7,3'-tetrametoksi-4'-hidroksi-8-C-prenilflavon (Hossain dan Rahman 2015). Eupatorin dan 3'-hidroksi-5,6,7,4'tetrametoksiflavon (TMF) diketahui memiliki aktivitas antioksidan yang relatif sama dengan butylated hydroxylanisole (BHA) sedangkan aktivitas antioksidan sinensitin lebih rendah dari BHA pada konsentrasi yang sama $(0,05 \mathrm{mg} / \mathrm{mL}$ ) (Akowuah et al., 2005).

Tabel 2. Karakteristik IR senyawa aktif terhadap aktivitas penghambatan enzim a-glukosidase berdasarkan nilai $Y$-related coefficient dan VIP

\begin{tabular}{|c|c|c|c|c|}
\hline Seny awa & $\begin{array}{l}\text { Bilangan } \\
\text { Gelombang } \\
\left(\mathrm{cm}^{-1}\right)\end{array}$ & $\begin{array}{l}\text { Y-related } \\
\text { Coe- } \\
\text { fficients }\end{array}$ & VIP & Ref. \\
\hline \multirow[t]{2}{*}{ Sinensitin } & $\begin{array}{l}2850 \\
1215\end{array}$ & $\begin{array}{l}+ \\
+\end{array}$ & $\begin{array}{l}0,72 \\
0,67\end{array}$ & $\begin{array}{l}\text { Hossain } \\
\text { dan }\end{array}$ \\
\hline & 1189 & + & 0,72 & \multirow{4}{*}{$\begin{array}{l}\text { Rahman, } \\
2015\end{array}$} \\
\hline 5,6,7,3'- & 2964 & + & 0,69 & \\
\hline tetrametoksi- & 2936 & + & 1,13 & \\
\hline 4'-hidroksi-8- & 1271 & + & 0,93 & \\
\hline C-prenilf lav on & 1200 & + & 0,77 & \multirow{5}{*}{$\begin{array}{l}\text { Ohashi } \\
\text { et al., } \\
2000\end{array}$} \\
\hline \multirow[t]{2}{*}{ Neoortosif ol A } & 1720 & + & 1,01 & \\
\hline & 1267 & + & 0,88 & \\
\hline \multirow[t]{2}{*}{ Neoortosif ol B } & 1720 & + & 1,01 & \\
\hline & 1250 & + & 0,75 & \\
\hline \multirow[t]{2}{*}{ Ortosif ol O } & 1725 & + & 0,94 & \multirow{6}{*}{$\begin{array}{l}\text { Awale } \\
\text { et al., } \\
2002\end{array}$} \\
\hline & 1280 & + & 0,98 & \\
\hline \multirow[t]{2}{*}{ Ortosif ol P } & 1720 & + & 1,01 & \\
\hline & 1275 & + & 0,96 & \\
\hline \multirow[t]{2}{*}{ Ortosif ol Q } & 1725 & + & 0,94 & \\
\hline & 1265 & + & 0,86 & \\
\hline \multirow{2}{*}{$\begin{array}{l}\text { Noortosif onoli } \\
\text { da A }\end{array}$} & 1720 & + & 1,01 & \\
\hline & 1285 & + & 0,94 & \multirow{8}{*}{$\begin{array}{l}\text { Masuda et } \\
\text { al., } 1992\end{array}$} \\
\hline \multirow[t]{3}{*}{ Ortosif ol A } & 2967 & + & 0,60 & \\
\hline & 1723 & + & 0,98 & \\
\hline & 1287 & + & 0,89 & \\
\hline \multirow[t]{4}{*}{ Ortosif ol B } & $\begin{array}{l}1<40 \\
2970\end{array}$ & $\begin{array}{l}+ \\
+\end{array}$ & $\begin{array}{l}0.69 \\
0,40\end{array}$ & \\
\hline & 1717 & + & 1,12 & \\
\hline & 1289 & + & 0,82 & \\
\hline & 1240 & + & 0.69 & \\
\hline \multirow[t]{3}{*}{ Ortosif ol U } & 1720 & + & 1,01 & \multirow{16}{*}{$\begin{array}{l}\text { Awale } \\
\text { et al., } \\
2003\end{array}$} \\
\hline & 1210 & + & 0,72 & \\
\hline & 1180 & + & 0,80 & \\
\hline \multirow[t]{3}{*}{ Ortosif ol V } & 1720 & + & 1,01 & \\
\hline & 1210 & + & 0,72 & \\
\hline & 1180 & + & 0,80 & \\
\hline \multirow[t]{3}{*}{ Ortosif ol W } & 1725 & + & 0,94 & \\
\hline & 1210 & + & 0,72 & \\
\hline & 1180 & + & 0,80 & \\
\hline \multirow[t]{3}{*}{ Ortosif ol X } & 1720 & + & 1,01 & \\
\hline & 1210 & + & 0,72 & \\
\hline & 1175 & + & 0,81 & \\
\hline Ortosif ol $Y$ & 1735 & + & 0,66 & \\
\hline & 1210 & + & 0,72 & \\
\hline Ortosif ol Z & 1725 & + & 0,94 & \\
\hline & 1265 & + & 0,86 & \\
\hline Ortosif ol F & 1725 & + & 0,94 & Tezuka et \\
\hline & 1280 & + & 0,98 & al., 2000 \\
\hline Ortosif ol G & 1720 & + & 1,01 & \\
\hline & 1280 & + & 0,98 & \\
\hline Ortosif ol H & 1725 & + & 0,94 & \\
\hline & 1280 & + & 0,98 & \\
\hline & 1240 & + & 0,69 & \\
\hline Ortosif ol I & 1725 & + & 0,94 & \\
\hline & 1270 & + & 0,91 & \\
\hline Ortosiphol J & 1725 & + & 0,94 & \\
\hline & 1270 & + & 0,91 & \\
\hline & 1230 & + & 0,63 & \\
\hline Staminol A & 1725 & + & 0,94 & \\
\hline
\end{tabular}

\begin{tabular}{|c|c|c|c|c|}
\hline Seny awa & $\begin{array}{l}\text { Bilangan } \\
\text { Gelombang } \\
(\mathrm{cm}-1)\end{array}$ & $\begin{array}{c}\text { Y-related } \\
\text { Coe- } \\
\text { fficients }\end{array}$ & VIP & Ref. \\
\hline & 1200 & + & 0,77 & \\
\hline & 1270 & + & 0,91 & \\
\hline \multirow[t]{3}{*}{ Staminol B } & 1725 & + & 0,94 & \\
\hline & 1200 & + & 0,77 & \\
\hline & 1270 & + & 0,91 & \\
\hline Staminolakton & 1730 & + & 0,83 & \\
\hline \multirow[t]{2}{*}{ A } & 1200 & + & 0,77 & \\
\hline & 1240 & $\begin{array}{l}7 \\
+\end{array}$ & 0,67 & \\
\hline Staminolakton & 1730 & + & 0,83 & \\
\hline \multirow[t]{3}{*}{ B } & 1270 & + & 0,91 & \\
\hline & 1200 & + & 0,77 & \\
\hline & 1240 & + & 0,67 & \\
\hline \multirow[t]{4}{*}{ Norstaminol A } & 1725 & + & 0,94 & \\
\hline & 1280 & + & 0,98 & \\
\hline & 1200 & + & 0,77 & \\
\hline & 1240 & + & 0,67 & \\
\hline \multirow{2}{*}{ Ortoarisin A } & 1716 & + & 1,12 & $\mathrm{Di}$ \\
\hline & 1275 & + & 0,96 & et al., \\
\hline \multirow[t]{2}{*}{ Ortoarisin B } & 1716 & + & 1,12 & 2013 \\
\hline & 1279 & + & 0,98 & \\
\hline \multirow[t]{2}{*}{ Ortoarisin C } & 1720 & + & 1,01 & \\
\hline & 1276 & + & 0,93 & \\
\hline Ortoarisin D & 1712 & + & 1,19 & \\
\hline & 1238 & + & 0,67 & \\
\hline Ortoarisin E & 2972 & + & 0,32 & \\
\hline & 2944 & + & 0,77 & \\
\hline & 2883 & + & 0,04 & \\
\hline & 1729 & + & 0,86 & \\
\hline & 1276 & + & 0,93 & \\
\hline Ortoarisin $\mathrm{F}$ & 2970 & + & 0,42 & \\
\hline & 2938 & + & 1,02 & \\
\hline & 2881 & + & 0,06 & \\
\hline & 1725 & + & 0,94 & \\
\hline & 1283 & + & 0,78 & \\
\hline & 1235 & + & 0,65 & \\
\hline & 1174 & + & 0,81 & \\
\hline Ortoarisin G & 2970 & + & 0,42 & \\
\hline & 2938 & + & 1,02 & \\
\hline & 2881 & + & 0,06 & \\
\hline & 1725 & + & 0,94 & \\
\hline & 1283 & + & 0,78 & \\
\hline & 1235 & + & 0,65 & \\
\hline & 1174 & + & 0,81 & \\
\hline Ortoarisin $\mathrm{H}$ & 1731 & + & 0,79 & \\
\hline & 1277 & + & 0,97 & \\
\hline & 1244 & + & 0,71 & \\
\hline Ortoarisin I & 1718 & + & 1,06 & \\
\hline & 1271 & + & 0,93 & \\
\hline Asam ursolat & 1293 & + & 0,62 & Hossain \\
\hline & 1216 & + & 0,65 & dan Ismail, \\
\hline & 963 & + & 0,07 & 2013 \\
\hline Asam & 2876 & + & 0,18 & \\
\hline oleanolat & 1265 & + & 0,86 & \\
\hline & 1227 & + & 0,62 & \\
\hline & 964 & + & 0,06 & \\
\hline Asam & 2953 & + & 0,78 & \\
\hline betulinat & 2887 & + & 0,04 & \\
\hline & 1682 & + & 0,57 & \\
\hline & 1221 & + & 0,63 & \\
\hline & 1194 & + & 0,73 & \\
\hline & 980 & + & 0,00 & \\
\hline Asam & 2926 & + & 1,63 & \\
\hline hidroksi- & 1742 & + & 0,46 & \\
\hline betulinat & 1254 & + & 0,77 & \\
\hline & 975 & + & 0,07 & \\
\hline$\alpha$-amirin & 2969 & + & 0,51 & \\
\hline & 2931 & + & 1,36 & \\
\hline & 2849 & + & 0,61 & \\
\hline & 1254 & + & 0,77 & \\
\hline & 969 & + & 0,07 & \\
\hline$\beta$-amirin & 2964 & + & 0,69 & \\
\hline & 2920 & + & 1,67 & \\
\hline & 1753 & + & 0,08 & \\
\hline & 1260 & + & 0,81 & \\
\hline Asam & 2926 & + & 1,63 & \\
\hline maslinat & 1742 & + & 0,46 & \\
\hline & 1254 & + & 0,77 & \\
\hline & 975 & + & 0,07 & \\
\hline
\end{tabular}


Aktivitas antioksidan oleh flavonoid dan senyawa fenol lainnya sebagian besar disebabkan oleh gugus hidroksil aromatik sehingga radikal fenolik menjadi lebih stabil langsung setelah radikal terbentuk ketika satu hidrogen radikal didonorkan ke DPPH (de Souza et al., 2013). Semakin banyak gugus hidroksi pada struktur kimia semakin tinggi aktivitas antioksidan oleh senyawa tersebut (Liu et al., 2010). Sebaliknya, flavonoid yang disubtitusi dengan sejumlah metoksi menunjukkan penurunan aktivitas antioksidan (Jeong et al., 2007). Senyawa diterpen ditandai dengan adanya pita serapan gugus hidroksil pada bilangan gelombang $3500-3480 \mathrm{~cm}^{-1}$, ester karbonil pada bilangan gelombang 1270-1150 $\mathrm{cm}^{-1}$, dan fenil pada bilangan gelombang $1600 \mathrm{~cm}^{-1}$ dan $1420 \mathrm{~cm}^{-1}$ (Sim et al., 2004).

Tabel 3. Karakteristik IR senyawa aktif terhadap aktivitas antioksidan berdasarkan nilai $Y$ related coefficient dan VIP

\begin{tabular}{|c|c|c|c|c|}
\hline Seny awa & $\begin{array}{l}\text { Bilangan } \\
\text { Gelombang } \\
\left(\mathrm{cm}^{-1}\right)\end{array}$ & $\begin{array}{c}\text { Y-related } \\
\text { Coe- } \\
\text { fficients }\end{array}$ & VIP & Ref. \\
\hline \multirow[t]{3}{*}{ Asam rosmarinat } & 3382 & + & 0,66 & \multirow{21}{*}{$\begin{array}{l}\text { Abedini } \\
\text { et al., } \\
2013 \\
\text { Hossain } \\
\text { dan } \\
\text { Rahman, } \\
2015\end{array}$} \\
\hline & 1606 & + & 0,21 & \\
\hline & 1522 & + & 0,11 & \\
\hline \multirow[t]{4}{*}{ Eupatorin } & 3470 & + & 0,44 & \\
\hline & 3250 & + & 0,55 & \\
\hline & 1605 & + & 0,22 & \\
\hline & 1599 & + & 0,31 & \\
\hline \multirow[t]{2}{*}{ Sinensitin } & 1600 & + & 0,27 & \\
\hline & 1590 & + & 0,23 & \\
\hline 5-hidroksi-6,7,3',4'- & 3415 & + & 0,52 & \\
\hline \multirow[t]{2}{*}{ tetrametoksf lavon } & 1600 & + & 0,27 & \\
\hline & 1590 & + & 0,23 & \\
\hline \multirow[t]{3}{*}{ Salvegenin } & 3450 & + & 0,52 & \\
\hline & 1600 & + & 0,27 & \\
\hline & 1590 & + & 0,23 & \\
\hline 6-hidroksi-5,7,3'- & 3470 & + & 0,44 & \\
\hline \multirow[t]{2}{*}{ trimetoksif lavon } & 1595 & + & 0,33 & \\
\hline & 1590 & + & 0,23 & \\
\hline \multirow{3}{*}{$\begin{array}{l}5,6,7,3 \text { '- } \\
\text { tetrametoksi-4'- } \\
\text { hidroksi-8-C- } \\
\text { prenilf lav on }\end{array}$} & 3435 & + & 0,43 & \\
\hline & 1610 & + & 0,19 & \\
\hline & 1595 & + & 0,33 & \\
\hline \multirow[t]{2}{*}{ Neoortosif ol A } & 3420 & + & 0,61 & \multirow{4}{*}{$\begin{array}{l}\text { Ohashi } \\
\text { et al., } \\
2000\end{array}$} \\
\hline & 3080 & + & 0,51 & \\
\hline \multirow[t]{2}{*}{ Neoortosif ol B } & 3410 & + & 0,55 & \\
\hline & 3080 & + & 0,51 & \\
\hline \multirow[t]{2}{*}{ Ortosif ol O } & 3550 & + & 0,19 & \multirow{8}{*}{$\begin{array}{l}\text { Awale et } \\
\text { al., } 2002\end{array}$} \\
\hline & 3400 & + & 0,50 & \\
\hline \multirow[t]{2}{*}{ Ortosif ol P } & 3550 & + & 0,19 & \\
\hline & 3450 & + & 0,52 & \\
\hline \multirow[t]{2}{*}{ Ortosif ol Q } & 3550 & + & 0,19 & \\
\hline & 3450 & + & 0,52 & \\
\hline \multirow[t]{2}{*}{ Noortosif onolida A } & 3550 & + & 0,19 & \\
\hline & 3450 & + & 0,52 & \\
\hline Ortosif ol A & 3425 & + & 0,62 & \multirow{14}{*}{$\begin{array}{l}\text { Masuda } \\
\text { et al., } \\
1992 \\
\text { Awale et } \\
\text { al., } 2003\end{array}$} \\
\hline Ortosif ol B & 3420 & + & 0,61 & \\
\hline \multirow[t]{3}{*}{ Ortosif ol U } & 3450 & + & 0,52 & \\
\hline & 1605 & + & 0,22 & \\
\hline & 1590 & + & 0,23 & \\
\hline \multirow[t]{3}{*}{ Ortosif ol V } & 3450 & + & 0,52 & \\
\hline & 1605 & + & 0,22 & \\
\hline & 1590 & + & 0,23 & \\
\hline \multirow[t]{3}{*}{ Ortosif ol W } & 3400 & + & $\begin{array}{l}0,50 \\
0 ? 2\end{array}$ & \\
\hline & 1605 & + & 0,22 & \\
\hline & 1590 & + & 0,23 & \\
\hline \multirow[t]{3}{*}{ Ortosif ol X } & 3450 & + & 0,52 & \\
\hline & 1605 & + & 0,22 & \\
\hline & 1585 & + & 0,09 & \\
\hline
\end{tabular}

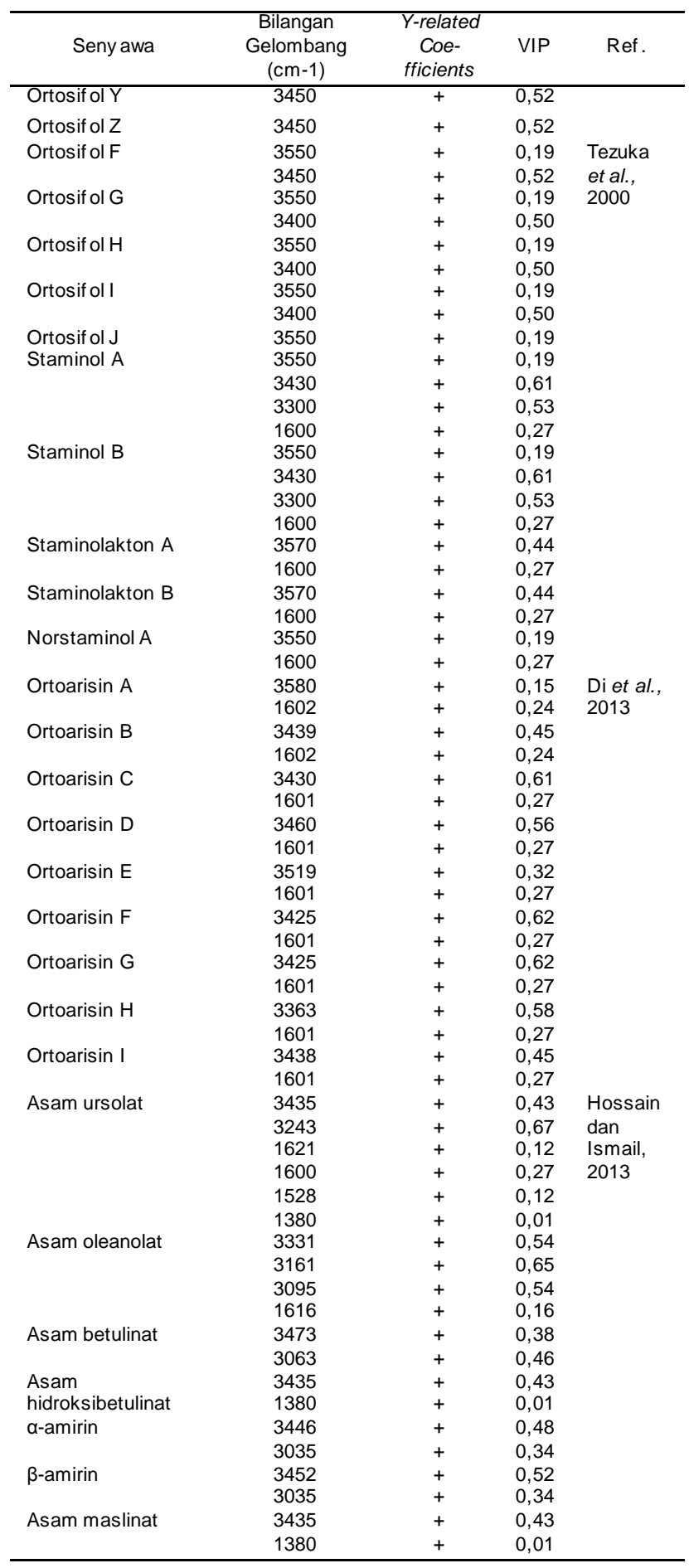

Berdasarkan hasil identifikasi gugus fungsi penanda senyawa antioksidan mengindikasikan senyawa dari kelompok diterpen tipe isopimaran yaitu ortosifol $F$, ortosifol $G$, ortosifol $H$, ortosifol I, ortosifol J (Tezuka et al., 2000), ortoarisin A, ortoarisin $B$, ortoarisin $C$, ortoarisin $D$, ortoarisin $E$, ortoarisin F dan ortoarisin G (Di et al., 2013). Diterpen tipe isopimaran teroksigenasi antara lain ortosifol $\mathrm{O}$, ortosifol $\mathrm{P}$, ortosifol $\mathrm{Q}$, dan noortosifonolida A (Awale et al., 2002), diterpen tipe isopimaran 
teroksigenasi tinggi antara lain ortosifol $A$, ortosifol $B$, ortosifol $U$, ortosifol $V$, ortosifol $W$, ortosifol $X$, ortosifol Y, dan ortosifol Z (Masuda et al., 1992; Awale et al., 2003), diterpen tipe isopimaran termigrasi neoortosifol A dan neoortosifol B (Ohashi et al., 2000) dan diterpen tipe sekoisopimaran ortoarisin $\mathrm{H}$ (Di et al., 2013). 18 senyawa diterpen (ortosifol U-Z, ortosifol A, B, D, F, G, I, J, O, R, T, ortosifonon $A$ dan sekoortosifol $B)$ diisolasi dari ekstrak metanol kumis kucing menujukkan aktivitas penghambatan yang signifikan terhadap produksi nitrit oksida (NO) pada sel serupa mikrofag J774,1 teraktivasi lipopolisakarida (LPS). Namun demikian ortosifol $A, B, D$, dan $X$ menunjukkan aktivitas penghambatan kuat melebihi kontrol positif NGmonometil-L-arginin (L-NMMA). Ortosifol $U$ menunjukkan aktivitas terkuat dengan nilai $I_{50}$ sebesar 6,4 $\mu \mathrm{M}$ (Awale et al., 2003).

Selain itu senyawa antioksidan juga diduga dari kelompok diterpen tipe staminan. Beberapa senyawa diterpen tipe staminan diidentifikasi yaitu staminol $A$, staminol $B$, staminolakton $A$, staminalakton B, norstaminol A (Tezuka et al., 2000) dan ortoarisin I (Di et al., 2013). Aktivitas antioksidan diterpen tipe staminan terhadap produksi nitrit oksida (NO) pada sel serupa mikrofag J774,1 teraktivasi lipopolisakarida (LPS) dilaporkan dari senyawa staminol C dan D yang diisolasi dari ekstrak metanol kumis kucing dengan nilai $\mathrm{IC}_{50}$ berturut-turut sebesar 61,1 $\mu \mathrm{M}$ dan 92,0 $\mu \mathrm{M}$ (Nguyen et al., 2004).

Berdasarkan hasil identifikasi gugus fungsi penanda senyawa antioksidan mengindikasikan senyawa dari kelompok triterpen yaitu asam ursolat, asam oleanolat, asam betulinat, asam hidroksibetulinat, $\alpha$-amirin, $\beta$-amirin, dan asam maslinat (Hossain dan Ismail, 2013) sebagai senyawa antioksidan. Asam ursolat yang diisolasi dari ekstrak Sambucus australis menunjukkan aktivitas antioksidan terhadap senyawa $\mathrm{DPPH}$ dengan nilai $\mathrm{IC}_{50}$ sebesar $5,97 \times 10^{-2} \mathrm{mg} / \mathrm{mL}$, asam maslinat yang diisolasi dari kulit buah Ziziphus jujuba Mill. menunjukkan aktivitas antioksidan terhadap DPPH setara standar BHT dengan nilai dengan nilai $\mathrm{IC}_{50}$ berturutturut sebesar 39,6; 28,12 $\mu \mathrm{g} / \mathrm{mL}$ (do Nascimento et al., 2014; Rajopadhye dan Upadhye, 2016). Aktivitas antioksidan juga dilaporkan dari triterpen $\beta$-amirin dari daun Symplocos cochinchinensis Moore. yang menunjukkan aktivitas antioksidan terhadap radikal DPPH ( $\left(\mathrm{C}_{50} 89,63 \mathrm{~g} / \mathrm{mL}\right)$, hidroksil $\left(\mathrm{IC}_{50} 76,41 \mathrm{~g} / \mathrm{mL}\right)$, nitrit oksida $\left(\mathrm{IC}_{50} 87,03 \mathrm{~g} / \mathrm{mL}\right)$ dan superoksida $\left(\mathrm{IC}_{50}\right.$ $81,28 \mathrm{~g} / \mathrm{mL}$ ) sekaligus aktivitas mereduksi radikal yang tinggi dan kuat dalam menekan pengaruh peroksidasi lipid (Sunil et al., 2014). Selain itu, senyawa triterpen $\alpha$-amirin, asam ursolat, dan asam oleanolat yang diisolasi dari $F$. pseudopalma merupakan pendonor proton dengan nilai $I_{50}$ $>333,33 \mu \mathrm{M}$ dan kemampuan mereduksi sebessar
$\mathrm{RC}_{50}>909.09 \mu \mathrm{M}$. Asam ursolat merupakan penghambat $\mathrm{NO} \cdot$ tertinggi $\left(\mathrm{IC}_{50}>166,67 \mu \mathrm{M}\right)$ yang disusul asam oleanolat dan kemudian a-amirin. Asam ursolat juga merupakan penghambat radikal $\bullet 02$ tertinggi. Tidak hanya itu, $\alpha$-amirin, asam oleanolat dan asam ursolat menujukkan kemampuan menghambat peroksidasi lipid dengan nilai $I_{50}<15 \mu \mathrm{M}$ (Santiago et al., 2014).

\section{KESIMPULAN}

Metode metabolomik berbasis FTIR memungkinkan identifikasi secara cepat gugus fungsional penanda senyawa yang berkorelasi positif dengan aktivitas penghambatan enzim a-glukosidase dan antioksidan dari ekstrak kasar dan fraksi kumis kucing. Hasil analisis menunjukkan bahwa gugus fungsi karbonil, metoksi, hidroksil dan C-O yang mengindikasikan keberadaan senyawa dari kelompok metoksi flavonoid (sinensitin dan 5,6,7,3'tetrametoksi-4'-hidroksi-8-C-prenilflavon), diterpena (ortosifol, ortoarisin, neoortosifol, staminol, dan staminolakton), triterpena (asam ursolat, asam oleanolat, asam betulinat, asam hidroksibetulinat, asam maslinat, $\alpha$-amirin dan $\beta$-amirin) diidentifikasi sebagai senyawa penghambat aktivitas enzim $\alpha$ glukosidase sedangkan fenolik (asam rosmarinat), flavonoid (eupatorin, sinensetin, 5-hidroksi-6,7,3', 4'tetrametoksiflavon, salvigenin, 6-hidroksi-5,7,3'trimetoksiflavon dan 5,6,7,3'-tetrametoksi-4'-hidroksi-8-C-prenilflavon), diterpena (ortosifol, ortoarisin, neoortosifol, staminol, dan staminalakton), triterpena (asam ursolat, asam oleanolat, asam betulinat, asam hidroksibetulinat, asam maslinat, $\alpha$-amirin dan $\beta$-amirin) diidentifikasi sebagai senyawa antioksidan. Untuk konfirmasi, senyawa-senyawa tersebut dapat diisolasi dan diuji aktivitas penghambatan enzim $\alpha$ glukosidase dan antioksidannya. Dengan adanya informasi dari analisis OPLS ini, maka proses isolasi dan identifikasi akan jauh lebih mudah dan terarah.

\section{UCAPAN TERIMAKASIH}

Penelitian ini dapat terlaksana atas bantuan dari Riset Inovatif Produktif (RISPRO) Lembaga Pengelola Dana Pendidikan (LPDP) bekerja sama dengan PT Soho Industri Farmasi.

\section{DAFTAR PUSTAKA}

Abdelwahab SI, Mohan S, Elhassan MM, AlMekhlafi N, Mariod AA, Abdul AB, Abdulla MA. Alkharfy $\mathrm{KH}$. 2011. Antiapoptotic and antioxidant properties of Orthosiphon stamineus benth (cat's whiskers): intervention in the Bcl-2mediated apoptotic pathway. Evid-Based 
Compl Alt Med 2011: 1-11. DOI: 10.1155/2011/ 156765.

Abedini A, Roumy V, Mahieux S, Biabiany M, Standaert-Vitse A, Rivière $C$, Sahpaz $S$, Bailleul F, Neut C, Hennebelle T. 2013. Rosmarinic acid and its methyl ester as antimicrobial components of the hydromethanolic extract of Hyptis atrorubens poit. (lamiaceae). Evid-Based Compl Alt Med 2013: 1-11. DOI: 10.1155/ 2013/604536.

Adnyana IK, Setiawan F, Insanu M. 2013. From ethnopharmacology to clinical study of Orthosiphon stamineus Benth. Int J Pharm Sci 5: 6366.

Akowuah GA, Ismail Z, Norhayati I, Sadikun A. 2005. The effects of different extraction solvents of varying polarities on polyphenols of Orthosiphon stamineus and evaluation of the free radical-scavenging activity. Food Chem 93: 311-317. DOI: 10.1016/j.foodchem.2004.09.02 8.

Asghari B, Salehi P, Sonboli A, Nejad ES. 2015. Flavonoids from Salvia chloroleuca with $\alpha$ amylsae and a-glucosidase inhibitory effect. Iran J Pharm Res 14: 609-615.

Awale S, Tezuka Y, Banskota AH, Kouda K, Tun KM, Kadota S. 2002. Four highly oxygenated isopimarane-type diterpenes of Orthosiphon stamineus. Planta Med 68: 286-288. DOI: 10.1055/s-2002-23137.

Awale S, Tezuka Y, Banskota AH, I Ketut Adnyana, Kadota S. 2003. Nitric oxide inhibitory isopimarane-type diterpenes from Orthosiphon stamineus of Indonesia. J Nat Prod 66: 255-8. DOI: $10.1021 / \mathrm{np} 020455 x$.

Baynes JW, Thorpe SR. 1999. Perspectives in diabetes: Role of oxidative stress in diabetic complications a new perspective on an old paradigm. Diabetes 48: 1-09.

Capasso R, Izzo AA, Romussi G, Capasso F, De Tommasi N, Bisio A, Mascolo N. 2004. A secoisopimarane diterpenoid from Salvia cinnabarina inhibits rat urinary bladder contractility in vitro. Planta Med 70: 185-8. DOI: 10.1055/s-2004-815501.

Damsud T, Grace MH, Adisakwattana S, Phuwapraisirisan P. 2014. Orthosiphol A from the aerial parts of Orthosiphon aristatus is putatively responsible for hypoglycemic effect via alpha-glucosidase inhibition. Nat Prod Commun 9: 639-41.

de Souza RF, Marinho VHS, da Silva GA, Costa-Jr. LM, da Silva JKR, Bastos GNT, Arruda AC, da Silva MN, Arruda MSP. 2013. New isoflvones from the leaves of Vatairea guianensis aublé. J
Brazil Chem Soc 24: 1857-1863. DOI: 10.5 935/0103-5053.20130231.

Di XX, Wang SQ, Zhang XL, Wang B, Lou XL, Wang XN. 2013. Diterpenoids from the aerial parts of Orthosiphon aristatus var. aristatus. Phytochem Lett 6: 412-417. DOI: 10.1016/j.phytol.2013. 05.015.

Di Sotto A, Mastrangelo $S$, Romussi $G$, Bisio $A$, Mazzanti G. 2009. Antimutagenic activity of a secoisopimarane diterpenoid from Salvia cinnabarina M. Martens et Galeotti in the bacterial reverse mutation assay. Food Chem Toxicol 47: 2092-2096. DOI: 10.1016/j.fct. 2009.05.030.2.

do Nascimento PG, Lemos TL, Bizerra AM, Arriaga ÂM, Ferreira DA, Santiago GM, Braz-Filho R, Costa JG. 2014. Antibacterial and antioxidant activities of ursolic acid and derivatives. Molecules 19: 1317-1327. DOI: 10.3390/mole cules 19011317.

Eriksson L, Johansson E, Wold N, Trygg J, Wikstrom C, Wold S. 2006. Multi- and Megavariate Data Analysis: Advanced Appli-cations and Method Extensions. 1st ed. 103-119. Umetrics AB, Umea Sweden.

Eriksson L, Trygg J, Wold S. 2008. CV-ANOVA for significance testing of PLS and OPLS models. J Chemometr 22: 594-600. DOI: 10.1002/cem. 1187.

Galindo-Prieto B, Eriksson L, Trygg J. 2014. Variable influence on projection (VIP) for orthogonal projections to latent structures (OPLS). J Chemometr 28: 623-632. DOI: 10.1002/cem.26 27.

He QQ, Yang L, Zhang JY, Ma JN, Ma CM. 2014. Chemical constituents of gold-red apple and their a-glucosidase inhibitory activities. J Food Sci 79: C1970-83. DOI: 10.1111/1750-3841.125 99.

Hossain MA, Rahman SMM. 2015. Isolation and characterisation of flavonoids from the leaves of me dicinal plant Orthosiphon stamineus. Arab J Chem 8: 218-221. DOI: 10.1016/j.arabjc. 2011.06.016.

Hossain MA, Ismail Z. 2013. Isolation and characterizati on of triterpenes from the leaves of Orthosiphon stamineus. Arab J Chem 6: 295-298. DOI: 10.1016/j.arabjc.2010.10.009.

Hou W, Li Y, Zhang Q, Wei X, Peng A, Chen L, Wei $Y$. 2009. Triterpene acids isolated from Lagerstroemia speciosa leaves as alpha-glucosidase inhibitors. Phytother Res 23: 614-618. DOI: 10.1002/ptr.2661.

Hunaefi D, Akumo DN, Riedel H, Smetanska I. 2012. The effect of Lactobacillus plantarum ATCC 
8014 and Lactobacillus acidophilus NCFM fermentation on antioxidant properties of selected in vitro sprout culture of Orthosiphon aristatus (Java Tea) as a Model Study. Antioxidants (Basel) 1: 4-32. DOI: 10.3390/anti ox1010004.

Hussain K, Ismail Z, Sadikun A, Ibrahim P. 2009. Evaluation of metabolic changes in fruit of Piper sarmentosum in various seasons by metabolomics using fourier transform infrared (FTIR) spectroscopy. Int J Clin Pharm Res 1: 68-71.

Jeong JM, Choi CH, Kang SK, Lee IH, Lee JY, Jung H. 2007. Antioxidant and chemosensitizing effects of flavonoids with hydroxy and/or methoxy groups and structure-activity relationship. J Pharm Pharm Sci 10: 537-46.

Khamsiah SM, Akowah G, Zhari I. 2006. Antioxidant activity and phenolic content of Orthosiphon stamineus benth from different geographical origin. J Sustain Sci Manage 1: 14-20.

Kwon YI, Apostolidis E, Shetty K. 2008. In vitro studies of eggplant (Solanum melongena) phenolics as inhibitors of key enzymes relevant for type 2 diabetes and hypertension. Bioresour Technol 99: 2981-8. 10.1016/j.biortech.2007. 06.035.

[IDF] International Diabetes Federation. 2013. Diabetes atlas. Sixth edition. http://www.idf.org/ diabetesatlas. [28 Februari 2014].

Lindgren F, Hansen B, Karcher W. 1996. Model validation by permutation tests: applications to variable selection. J Chemometr 10: 521-532. DOI: $\quad 10.1002 /(\mathrm{SICl}) 1099-128 X(199609) 10: 5 / 6<$ 521::AID-CEM448>3.0.CO;2-J.

Liu W, Yu Y, Yang R, Wan C, Xu B, Cao S. 2010. Optimization of total flavonoid compound extraction from Gynura medica leaf using response surface methodology and chemical composition analysis. Int $\mathrm{J}$ Mol Sci 11: 47504763. DOI: 10.3390/ijms11114750.

Masuda T, Masuda K, Shiragami S, Jitoe A, Nakatani N. 1992. Orthosiphol A and B, novel diterpenoid inhibitors of TPA (12-O- Tetradecanoylphorbol-13-acetate)-induced inflammation, from Orthosiphon stamineus. Tetrahedron 48: 6787-6792. DOI: 10.1016/ S00404020(01)898 68-9.

Mbaze LM, Poumale HM, Wansi JD, Lado JA, Khan SN, lqbal MC, Ngadjui BT, Laatsch H. 2007. alpha-Glucosidase inhibitory pentacyclic triterpenes from the stem bark of Fagara tessmannii (Rutaceae). Phytochemistry 68: 591-5. DOI: 10.1016/j.phytochem.2006.12.015.

Mohamed EAH, Mohamed AJ, Asmawi MZ, Sadikun A, Ebrika OS, Yam MF. 2011. Antihyper- glycemic effect of Orthosiphon stamineus benth leaves extract and its bioassay-guided fractions. Molecules 16: 3787-3801. DOI: 10.33 90/molecules 16053787.

Mohamed EAH, Siddiqui MJA, Ang LF, Sadikun A, Chan SH, Tan SC, Asmawi MZ, Yam MF. 2012. Potent $\alpha$-glucosidase and $\alpha$-amylase inhibitory activities of standardized $50 \%$ ethanolic extracts and sinensetin from Orthosiphon stamineus Benth as anti-diabetic mechanism. BMC Complem Altern M 12: 01-07. DOI: 10.1186/1472-6882-12-176.

Nguyen MT, Awale S, Tezuka Y, Chien-Hsiung C, Kadota S. 2004. Staminane- and isopimaranetype diterpenes from Orthosiphon stamineus of Taiwan and their nitric oxide inhibitory activity. J Nat Prod 67: 654-8. DOI: 10.1021/np030471+.

Ohashi K, Bohgaki T, Matsubara T, Shibuya H. 2000. Indonesian medicinal plants. XXIII. Chemical structures of two new migrated pimarane-type diterpenes, neoorthosiphols A and $\mathrm{B}$, and suppressive effects on rat thoracic aorta of chemical constituents isolated from the leaves of Orthosiphon aristatus (Lamiaceae). Chem Pharm Bull (Tokyo) 48: 433-435.

Pop RM, Buzoianu AD, Raţi IV, Socaciu C. 2014. Untargeted metabolomics for sea buckthorn (Hippophae rhamnoides ssp. carpatica) berries and leaves: fourier transform infrared spectroscopy as a rapid approach for evaluation and discrimination. Not Bot Horti Agrobo 42: 545550. DOI: $10.1583 /$ nbha422 9654

Rafi M, Purwakusumah ED, Ridwan T, Barus B, Sutandi A, Darusman LK. 2015. Geographical classification of Java tea (Orthosiphon stamineus) from Java Island by FTIR spectrocopy combined with canonical variate analysis. J Sains Matematika 23: 25-31.

Rajopadhye A, Upadhye AS. 2016. Estimation of bioactive compound, maslinic acid by HPTLC, and $E$ valuation of hepatoprotective activity on fruit pulp of Ziziphus jujuba mill. Cultivars in India. Evid-Based Compl Alt 2016: 1-8. DOI: 10.1155/2016/4758734.

Saidan $\mathrm{NH}$, Hamil MSR, Memon AH, Abdelbari MM, Hamdan MR, Mohd KS, Majid AMSA, Ismail Z. 2015. Selected metabolites profiling of Orthosiphon stamineus Benth. leaves extracts combined with chemometrics analysis and correlation with biological activities. BMC Complem Altern M 15: 12-30. DOI: 10.1186/ s12906-015-08840 .

Salah EDR, Ma Q, Kandil ZA, El-Halawany AM. 2014. Triterpenes as uncompetitive inhibitors of a-glucosidase from flowers of Punica granatum 
L. Nat Prod Res 28: 2191-2194. DOI: 10.1080/ 14786419.2014.928292.

Salazar-Aranda R, P'erez-L'opez LA, L'opez-Arroyo J, Alan'is-Garza BA, de Torres NW. 2011. Antimicrobial and antioxidant activities of plants from Northeast of Mexico. Evid-Based Compl Alt 2011: 01-06. DOI: 10.1093/ecam/nep127.

Sancheti S, Sancheti S, Seo SY. 2009. Chaenomeles Sinensis: A potent $\alpha$-and $\beta$-glucosidase inhibitor. Am J Pharm Toxicol 4: 8-11. DOI: 10.3844/ajptsp.2009.8.11.

Santiago LA, Dayrit KC, Correa PCB, Mayor ABR. 2014. Comparison of antioxidant and free radical scavenging activity of triterpenes $\alpha$ amyrin, oleanolic acid and ursolic acid. J Nat Prod 7: 29-36.

Santos FA, Frota JT, Arruda BR, de Melo TS, de Carvalho Almeida da Silva AA, de Castro Brito GA, Chaves MH, Rao VS. 2012. Antihyperglycemic and hypolipidemic effects of $\alpha, \beta$ amyrin, a triterpenoid mixture from Protium heptaphyllum in mice. Lipids Health Dis 11: 98. DOI: 10.1186/1476-511X-11-98.

Siddiqui M, Hafizoh S, Zhari I, Sahib $H$, Helal M, Majid AA. 2009. Analysis of total proteins, polysaccharides and glycosaponins contents of Orthosiphon stamineus Benth. in spray and freeze dried methanol: water (1:1) extract and its contribution to cytotoxic and antiangiogenic activities. Pharmacognosy Res 1: 320-326.

Silva SD, Feliciano RP, Boas LV, Bronze MR. 2014. Application of FTIR-ATR to Moscatel dessert wines for prediction of total phenolic and flavonoid contents and antioxidant capacity. Food Chem 150: 489-493. DOI: 10.1016/j.food chem.2013.11.028.

Sim CO, Hamdan MR, Ismail Z, Ahmad MN. 2004. Assessment of herbal medicines by chemometrics-assisted interpretation of FTIR spectra. J Anal Chimica Acta 570: 116-123.

Shobana S, Sreerama YN, Malleshi NG. 2009. Composition and enzyme inhibitory properties of finger millet (Eleusine coracana L.) seed coat phenolics: Mode of inhibition of a-glucosidase and pancreatic amylase. Food Chem 115: 1268-1273. DOI: 10.1016/j.foodchem.2009.01. 042.

Sridevi H, Jayaraman P, Pachaiyappan P. 2015. Evaluation of $\alpha$-glucosidase inhibitory action of isolated compound beta amyrin from Memecylon umbellatum burm. Int J Pharmacogn Phytochem Res 7: 1033-1038.
Stehfest K, Boese M, Kerns G, Piry A, Wilhelm C. 2004. Fourier transform infrared spectroscopy as a new tool to determine rosmarinic acid in situ. J Plant Physiol 161: 151-156. DOI: 10.1078/0176-1617-01099.

Sunil C, Irudayaraj SS, Duraipandiyan V, AI-Dhabi $\mathrm{NF}$, Agastian P, Ignacimuthu S. 2014. Antioxidant and free radical scavenging effects of $\beta$ amyrin isolated from $S$. cochinchinensis Moore. Leaves. Ind Crop Prod 61: 510-516. DOI: 10.1016/j.indcrop.2014.07.005.

Tezuka Y, Stampoulis P, Banskota AH, Awale S, Tran KQ, Saiki I, Kadota S. 2000. Constituents of the Vietnamese medicinal plant Orthosiphon stamineus. Chem Pharm Bull (Tokyo) 48: 17119. DOI: $10.1248 / \mathrm{cpb} .48 .1711$.

Uddin G, Rauf A, Al-Othman AM, Collina S, Arfan M, Ali G, Khan I. 2012. Pistagremic acid, a glucosidase inhibitor from Pistacia integerrima. Fitoterapia 83: 1648-52. DOI: 10.1016/j.fitote. 2012.09.017.

Worley B, Powers R. 2013. Multivariate analysis in metabolomics. Current Metabolomics 1: 92107. DOI: $10.2174 / 2213235 X 11301010092$.

Verpoorte R, Choi YH, Kim HK. 2007. NMR-based metabolomics at work in phytochemistry. Phytochem Rev 6: 3-14. DOI: 10.1007/s11101-0069031-3.

Xia X, Qi J, Liu Y, Jia A, Zhang Y, Liu C, Gao C, She Z. 2015. Bioactive isopimarane diterpenes from the fungus, Epicoccum sp. HS-1, associated with Apostichopus japonicus. Mar Drugs 13: 1124-32. DOI: $10.3390 / \mathrm{md} 13031124$.

Yang $F$, Shi $H$, Zhang $X$, Yang $H$, Zhou $Q$, Yu L. 2013. Two new saponins from tetraploid jiaogulan (Gynostemma pentaphyllum), and their anti-inflammatory and a-glucosidase inhibitory activities. Food Chem 141: 3606-3613. DOI: 10.1016/j.foodchem.2013.06.015.

Yuliana ND, Khatib A, Verpoorte R, Choi YH. 2011. Comprehensive extraction method integrated with NMR metabolomics: a new bioactivity screening method for plants, adenosine A1 receptor binding compounds in Orthosiphon stamineus benth. Anal Chem 83: 6902-6906. DOI: 10.1021/ac201458n.

Yus of NA, Isha A, Ismail IS, Khatib A, Shaari K, Abas F, Rukayadi Y' 2015. Infrared-metabolomics approach in detecting changes in Andrographis paniculata metabolites due to different harvesting ages and times. J Sci Food Agr 95: 2533-43. DOI: 10.1002/jsfa.6987. 